IZA DP No. 9212

The Effects of Longer School Days on Mothers' Labor Force Participation

Matias Berthelon

Diana Kruger

Melanie Oyarzún

July 2015 


\title{
The Effects of Longer School Days on Mothers' Labor Force Participation
}

\author{
Matias Berthelon \\ Universidad Adolfo Ibáñez \\ Diana Kruger \\ Universidad Adolfo Ibáñez \\ and IZA \\ Melanie Oyarzún \\ Pontificia Universidad Católica de Valparaíso
}

Discussion Paper No. 9212

July 2015

IZA

P.O. Box 7240

53072 Bonn

Germany

Phone: +49-228-3894-0

Fax: +49-228-3894-180

E-mail: iza@iza.org

\begin{abstract}
Any opinions expressed here are those of the author(s) and not those of IZA. Research published in this series may include views on policy, but the institute itself takes no institutional policy positions. The IZA research network is committed to the IZA Guiding Principles of Research Integrity.

The Institute for the Study of Labor (IZA) in Bonn is a local and virtual international research center and a place of communication between science, politics and business. IZA is an independent nonprofit organization supported by Deutsche Post Foundation. The center is associated with the University of Bonn and offers a stimulating research environment through its international network, workshops and conferences, data service, project support, research visits and doctoral program. IZA engages in (i) original and internationally competitive research in all fields of labor economics, (ii) development of policy concepts, and (iii) dissemination of research results and concepts to the interested public.
\end{abstract}

IZA Discussion Papers often represent preliminary work and are circulated to encourage discussion. Citation of such a paper should account for its provisional character. A revised version may be available directly from the author. 


\section{ABSTRACT}

\section{The Effects of Longer School Days on Mothers' Labor Force Participation*}

Lack of adequate childcare is a main reason women cite for not participating in the labor force. We investigate the effect of a reform that lengthened school schedules from half to full days in Chile - essentially providing zero-cost childcare - on different maternal labor participation outcomes. We identify the effect of the policy from its implementation across municipalities over time and rule out alternative explanations, finding evidence of positive and important effects on participation and more permanent attachment to the labor force. Additionally, we also find results are driven by the provision of full day schooling in $1^{\text {st }}$ and $2^{\text {nd }}$ grades.

JEL Classification: $\quad \mathrm{H} 4, \mathrm{~J} 2, \mathrm{~J} 4, \mathrm{I} 2$

Keywords: full day schooling, primary education, female labor participation, education reform, Chile

Corresponding author:

Matias Berthelon

Universidad Adolfo Ibáñez

Av. Padre Hurtado 750

Viña del Mar

Chile

E-mail: matias.berthelon@uai.cl

\footnotetext{
* The authors would like to thank seminar participants at the University of Chile, the Catholic University of Chile, Oregon State University, University of Maryland, and the Inter American Development Bank. Berthelon and Kruger received financial support from Chile's National Committee of Scientific and Technological Research (Comisión Nacional de Investigación Científica y Tecnológica, CONICYT), through FONDECYT Project No. 1120882. The authors thank the Sub-Secretariat of Social Provision for granting permission for the use of Chile's Social Protection Surveys. All results, errors and omissions are sole responsibility of the authors.
} 


\section{Introduction}

Motherhood is one of the main determinants of inactivity among women worldwide. It is often women who suspend their labor force activities when they have children, and the possibility of reconciling work and family life is to some extent affected by public policies that address this issue, directly or indirectly. For instance, lack of family-friendly employment policies in the United States explains almost 30 percent of the decrease in U.S. women's labor force participation in the past 25 years (Blau and Kahn 2013).

Legislation that supports flexible work schedules has facilitated mothers' entry or re-entry into the labor market after child birth (Del Boca 2002). Another policy is access to childcare. Among women with school-age children, lack of child care is among the main reasons for not working and not seeking employment. A positive relationship between access to child care and mothers' ability to participate in the labor market has been established in the literature. ${ }^{1}$ The existing evidence is focused almost exclusively on children of preschool age, but much less is known about how child care arrangements for elementary school children impact the labor decisions of their mothers.

Young children in primary school also require adult supervision and care, so that the time spent in school is, in one sense, a form of child care during part of the day. However, a gap often exists between school hours and parents' work hours. This gap is an especially relevant question for families where both parents work, or for single-parent households. For instance, in the U.S. about half of all 6 to 12 year old children with employed mothers participated in some form of supervised child care arrangement while their mothers were at work (Capizzano et al. 2000), ${ }^{2}$ thus it is reasonable to expect that if children's daily school schedule changes, parental employment decisions may be affected, and it is more likely that mothers' labor outcomes will respond to such a change.

This paper analyzes the impact of an exogenous increase in the daily time that school-aged children spend in school on their mothers' short-term and more permanent labor force participation decisions. We analyze a nation-wide reform that took place in Chile, which extended the length of the school day by about 35 percent without increasing the length of the yearly school calendar. ${ }^{3}$ The implementation of the reform was gradual across Chilean municipalities, due mostly to budget and

\footnotetext{
${ }^{1}$ For theoretical discussions on the relationship between labor supply and child care, see Blau and Robins (1988) and Blau and Currie (2006).

${ }^{2}$ Supervised child care arrangements include before- and/or after-school programs, family child care centers, and care by an adult nanny, babysitter, or relative.

${ }^{3}$ For most schools, this meant changing from a system of half-day shifts, to one continuous full-day schedule. A typical half-day schedule is from 8:00 a.m. until 1:30 p.m., while a typical full-day schedule runs from 8:00 a.m. until 3:30 p.m.
} 
infrastructure constraints. We exploit this exogenous source of variation in access to full-day schools to identify the effect of access to child care on women's employment decisions.

By increasing the length of daily school schedules, the Full-Day School reform, which we refer to as FDS in this paper, ${ }^{4}$ significantly reduced the gap between school and employed parents' work hours, and essentially provided subsidized child care to children attending publicly funded schools in Chile. It is reasonable to expect that mothers responded to the increase in child care, since non-working Chilean mothers with children in primary-school age cite lack of adequate child care as the second most important reason for not seeking employment, after domestic household tasks. ${ }^{5}$

We identify the effect of the policy using a panel data model of female labor force participation, so that identification comes from individual changes in a woman's participation status as a response to a change in her access to full-day schools at the municipal level. We use access to full-day schools at the municipal level because in our data set we are not able to identify the schools in which children are actually enrolled. Our key assumption is that trends in women's labor outcomes were independent from the implementation of the FDS reform at the municipal level. Although this assumption is impossible to test, we present convincing evidence that it is met.

Our paper is a valuable contribution to the existing knowledge on the relationship between child care and mothers' employment. Although the literature has documented a relationship between child care access and mothers' participation, ${ }^{6}$ the studies to date have focused almost exclusively on pre-school children and much less is known on the effects of child care for children in primary school. School hours are often less than parents' work hours and schedules don't necessarily overlap, so that supervised child care arrangements are necessary before and/or after school, and during vacation periods. To the authors' best knowledge, the only published work analyzing school-age children is Graves (2013), who found that redistributing school days to a more continuous, yearround school calendar made child care arrangements more difficult and thus reduced labor force participation of mothers with children in elementary school. Our findings are therefore an important contribution to this question.

\footnotetext{
${ }^{4}$ The reform is referred to as JEC in Chile, due to the Spanish acronym of its official name, Jornada Escolar Completa, approved in law No.19,532.

${ }^{5}$ See Table 1. Authors' estimates based on Chile's national household survey, CASEN (2011).

${ }^{6}$ On the relationship between child care subsidies and mothers' LFP, see for instance Baker et al. (2008) and Lefebvre and Merrigan (2008); on the effect of child care access, see Gelbach (2002), Powell (2002), Lokshin (2004), Berlinski and Galiani (2007), Cascio (2009), and Fitzpatrick (2010, 2012).
} 
Another contribution of our work is that we analyze longer, more permanent attachment to the labor force. Our data set contains detailed employment histories, so that we are able to construct three different measures of labor force participation. First, we analyze a traditional measure for whether mothers participated anytime during the year of the survey. We are also interested in the effect of child care availability on more permanent participation in the labor force, which would suggest that formal child care arrangements can contribute to the stability of mothers' employment. We include two variables that capture attachment to the labor force: a categorical variable for whether mothers participated in the labor force more than $50 \%$ of the year of the survey, and a continuous variable measuring the fraction of the year working or seeking employment. These two variables allow us to have a deeper understanding of labor force attachment, employment stability, and their response to child care availability.

Finally, unlike previous studies, our econometric estimation uses a panel data model that controls for individuals' unobserved heterogeneity, which is an important determinant in labor decisions. These unobservable characteristics include differences in attachment to the labor force and/or preferences regarding child care arrangements, and other time-invariant unobservable traits; thus, we incorporate important factors that were omitted in prior research. ${ }^{7} \mathrm{We}$ also explore whether the FDS reform had heterogeneous effects for different groups of mothers, who may respond differently to the policy according to their age, marital status, being head of household, education, and presence of younger preschool children. Finally, we analyze whether the effect of FDS access was different for different grade levels. No previous work on the Chilean FDS reform has explored the variation of the FDS policy within schools.

We find that the expansion of the FDS program significantly increased mothers' labor force participation. Our estimates indicate that if FDS coverage increases by 45 percentage points — which is the change required to move to full coverage of the policy in our sample-mothers' labor force participation would increase by 11.9 percentage points, equivalent to 17 percent. In addition, we find that more permanent labor force attachment also increases with greater access to schools under FDS: with an increase of 45 percentage points in FDS coverage, both the probability of women participating for at least six months during the year and the fraction of the year they work or seek employment increase by 19 percentage points - which is equivalent to two months of work. These

\footnotetext{
7 Hernando (2009) and Contreras et al. (2010) analyze the impact of the FDS reform on women's labor force participation using repeated rounds of the national Chilean household survey, CASEN. Both papers find that the increased time children spend in school led to an increase in labor force participation of women.
} 
findings suggest that extending child care arrangements for primary school children can facilitate more stable employment for women.

We also find that the effects of FDS access differ by grade level: the positive effect of the policy is driven by access to schools that provide FDS in $1^{\text {st }}$ and $2^{\text {nd }}$ grades, while access to full days from $3^{\text {rd }}$ through $8^{\text {th }}$ grade does not seem to increase women's labor force participation, suggesting that mothers' employment choices are specially constrained when children are relatively young. This finding has important policy implications in Chile because the FDS law does not require that schools implement full days in $1^{\text {st }}$ and $2^{\text {nd }}$ grade, it is optional before $3^{\text {rd }}$ grade. Our findings suggest that extending the mandatory requirement of full days for the early grades would have the strongest effect fostering mothers' labor force participation.

We also explored heterogeneous effects of the FDS reform across mothers' age, marital status, education, and presence of pre-school children. We find that older mothers, mothers that have a spouse/partner, mothers with lower educational attainment and mothers without children of preschool age experience positive and larger responses to the increase in access to full day schools.

We are confident that our results are not capturing other factors at the municipal level that might be affecting female labor force participation. All our estimations control for pre-existing trends, and we performed a series of robustness checks that attempt to falsify our estimates and address the possibility of our results being driven by migration patterns. None of these exercises reject our estimates.

Our findings also suggest that the lack of family-friendly policies in Chile could explainat least partly - the country's low female participation rates, which is consistent with recent findings for other OECD countries (Blau and Kahn 2013). Although not an explicit goal of the policy, extending the school day in Chile, so that it became more synchronized with mother's employment schedules, had the indirect effect of promoting mothers' participation and more to more stable employment outcomes. Thus, if promoting women's participation in the labor force is a relevant public policy objective, then policies need to address the provision of child care not only for preschoolers but also for older, school aged children, who are not old enough to care for themselves.

The remainder of the paper is organized as follows: Section 2 presents a background review of the Chilean education system and the Full-Day School reform. Section 3 explains our identification strategy and the estimation methodology. Section 4 describes the data set and explains 
the variables that used in our estimates. Section 5 discusses our results and Section 6 presents our conclusions.

\section{Background: Chilean education system and the full-day school reform}

The Chilean education system, after early reforms carried out during the 1980's, is characterized by the existence of three types of schools. First, there are public schools which are run at the municipal level and their funding comes from a per-student subsidy from the central government and from resources that can be allocated by the municipality, based on their priorities and financial constraints. Second, there exist private subsidized schools, also called private-voucher schools, which are subsidized by the government receiving, as public schools, a per-student subsidy. Private subsidized schools are allowed to function as for-profit organizations, and they can also charge fees to their students under a regulated scheme that reduces the per-student subsidy as fees are increased. Third, there are private schools that do not receive public funding. These schools are allowed to freely set the fees they charge (Mizala and Romagera 2000). ${ }^{8}$

Within this context, another important feature of the Chilean education system relates to parents' or family choice of school. Unlike public school systems in other countries, such as the U.S., families are not obligated to send their children to a particular school corresponding to their geographic location or school district. Instead, families are allowed to freely choose the schools according to their preferences and financial capacity, and thus, they are allowed to apply to any school of their choice regardless of the municipality or school district in which they live. Private and private subsidized schools can select students but public (municipal) schools cannot. ${ }^{9}$

In the second half of the 1990's, Chile initiated a large-scale education reform along four main lines, one of them being the increase of instructional time though an increase in the amount of time students spent in the classroom without lengthening the school year. ${ }^{10}$ This reform came to be known as the Full Day Schooling (FDS) reform, and it mandated that all primary and secondary schools that receive public funds - municipal or private subsidized - must offer a full-day program

\footnotetext{
${ }^{8}$ Given that private schools — which represent $8 \%$ of the total enrollment - are not obligated to ascribe to the FDS program, we do not include them in our analysis.

${ }^{9}$ In this context, place of residence in not bound to school choice, although there is evidence that for parents proximity to school is a significant determinant in choice of school (Chumacero, Gómez and Paredes 2011).

${ }^{10}$ The other three lines of the reform were: methodological innovations at the classroom, curricular reforms and teacher's career development.
} 
by 2007 and 2010, respectively. Additionally, the FDS law mandates that all publicly funded schools created after 1997 must initiate operations as full-day schools. ${ }^{11}$

The reform, which has been implemented in Chile since 1997, also stated that if a school was to enter into the FDS regime, the school could choose not to offer all its grade levels under the FDS regime. For instance, it was possible for a school to offer FDS from $5^{\text {th }}$ to $8^{\text {th }}$ grade, but not for $3^{\text {rd }}$ and $4^{\text {th }}$ grade (full-day $1^{\text {st }}$ and $2^{\text {nd }}$ grade is not mandatory). However, all classes within a grade level had to be offered as FDS.

The reform also mandated the increase in the weekly school length. In primary schools, weekly academic hours had to increase from 30 to 38 hours in grades 3 to $6 .{ }^{12}$ For $7^{\text {th }}$ and $8^{\text {th }}$ grade, weekly hours went from 33 to 38 (García Huidobro and Concha 2009). ${ }^{13}$ In addition, there were also increases in time allocated for recesses and lunch, thus on average time spent at school increased by about 35 percent in primary schools without increasing the number of days in the academic calendar, which amounted to an additional 1.5 to 2 hours of daily classroom time.

The reform presented operational challenges that restructured how public schools function in Chile at both primary and secondary levels: some schools went from providing two half-day shifts to one full-day shift. As these challenges arose, the implementation of the reform was not immediate but gradual, due to infrastructure and financial constraints (in fact, its deadlines have been extended several times). The gradual implementation of the reform can be observed in Figure 1. It describes the evolution of primary school enrollment by FDS adscription. We can observe that it took 9 years for the enrollment in the FDS to surpass the traditional school schedules, and that by 2009-13 years after the launching of the reform-FDS coverage had reached only 66 percent of total primary school enrollment.

The FDS program has operational and infrastructure costs. The operational component includes variable costs that increase as a result of lengthening the amount of time children spend in school; for example, teachers' salaries, administrative costs, and the provision of school lunches. To cover operational costs, the per-student subsidy regularly paid to all public and voucher schools

\footnotetext{
11 The impact of the FDS reform in several outcomes has been studied. It has been found that it improved results of students' standardized tests (Bellei 2009), reduced teen pregnancy and juvenile crime (Berthelon and Kruger 2011), and improved cognitive test scores, reduced high-school dropout, and lowered adolescent motherhood (Pires and Urzua 2014).

12 One academic hour is equivalent to 45 minutes.

13 The reform also mandated changes in weekly academic hours for secondary schools. As we are focusing on mother with children in primary schools only those changes are discussed.
} 
increased by $40 \%$. The most important expense (and constraint) associated with a full-day school is the expansion of schools' infrastructure to accommodate, in many cases, twice the number of students at any given time. Schools that wish to change their operations to FDS compete for public funds through an application process with the Ministry of Education, where they submit their academic plans and request the required funds to operate under the full day regime. ${ }^{14}$

In the funds application process, schools competed for limited capital infrastructure funds to finance their infrastructure requirements, and given the criteria for selection, the Ministry of Education does not allocate FDS funds randomly. Therefore the first schools that entered the program were schools with relatively low switch costs (i.e., rural schools with excess capacity) and priority schools with pre-existing deficits in infrastructure and located in areas of socio-economic vulnerability. ${ }^{15}$

Although child care was not an explicit goal of the policy, by increasing the time that children spend in school and the number of hours they receive adult care, the FDS policy was an implicit child care subsidy for school-aged children, which may impact the employment decisions of their mothers. Since mothers with children in primary school report lack of child care as an important determinant of inactivity (see Table 1), the FDS policy should lead to an increase in women's participation. Although the reform was implemented in both primary and secondary schools, we focus only on the impact of primary full-day school availability on mothers' labor force participation decisions, because lack of child care is not a relevant concern to mothers with children in secondary school (Table 1).

Identification in our empirical estimations relies on the fact that the school system is highly decentralized, and therefore the FDS program was taken up at different rates across Chilean administrative regions and municipalities. Table 2 presents the pace of implementation of the program in primary schools across Chile's thirteen administrative Regions, ${ }^{16}$ from the initial year of the reform until 2009, indicating the average share of primary schools that were under a full-day

\footnotetext{
${ }^{14}$ Law No. 19.532 of 1997 indicates that the Ministry of Education will grant schools authorization to operate under the full-day regime and also, through special competitive programs, will provide funds to schools that require additional resources to implement the FDS schedule. The Law also states that in granting both authorizations and funds the Ministry might use one or more of the following four selection criteria: a) Socio-economic or educational vulnerability of the school's students; b) Amount of resources requested on a per-student basis; c) Quality of the proposal with regard to technical, pedagogical, economic and social specifications; and d) Percentage of total requested funding that would be covered by the school's own administration.

${ }^{15}$ In section 3 we discuss how the non-random funds allocation rules may affect our empirical strategy.

${ }^{16}$ Each administrative Region in Chile is sub-divided into municipalities.
} 
regime; the last column of Table 2 is the relative size of the primary student population in each region.

We observe that even though there has been a sustained increase in full day school coverage, which has increased more than 60 percent between 2004 and 2009, there is also a large variability in reform take-up. As of 2009, in some regions more than 80 percent of schools are FDS whereas in others inclusion into the program only reaches 20 percent of all schools. At the same time there is an inverse relationship between enrollment and FDS implementation. The Metropolitan Region (XIII), where Santiago is located, was home to 36 percent of Chilean primary school students in 2009, yet there the reform was slowest - with 20 percent take-up - mainly because schools in this predominantly urban area have physical space constraints or higher costs of expansion of their infrastructure. The fastest implementation occurred in the sparsely populated IX, X and XI Regions, comprised mostly of rural areas and small cities and where a total of approximately 15 percent of primary school students reside. In each of these regions, about 83 percent of primary schools were full day by 2009 .

Table 3 reports the evolution of FDS coverage at the municipal level. As there are more than 330 municipalities in Chile, we report a table with the fraction of all municipalities in the country which fall within ranges of FDS implementation. We observe an increase over time in the share of municipalities reaching high levels of coverage, and at the same time a decrease in the number of municipalities with low coverage levels. An important feature of the evolution of municipality FDS is that there is a wide variety of FDS implementation levels and any given year, particularly for the years in which we compute our estimates. This can also be seen more clearly in Figure 2, which presents a map of Chile with the depth of FDS implementation across municipalities between 2004 and 2009.

In sum, both tables and figure reveal that the reform had significant temporal and municipal variation in the depth of its implementation. Our identification strategy is partly based on this quasiexperimental nature of the reform's implementation at the municipal level.

\section{Identification and estimation}

Before discussing our identification strategy, we discuss properties of our data and of the FDS reform that play a crucial role in determining the estimation methodology. A first issue is related to our data set. Chile's Social Protection Survey (EPS), which is the source of our labor market 
outcomes, does not include information of the school that children attend, so it is not possible for us to estimate the direct effect of attending an FDS school on mothers' labor force participation outcomes. Therefore, we construct a variable that measures potential access, or availability to FDS schools at the municipality level - the smallest geographical level at which we can operate with this data set.

One concern could be that due to school choice in Chile, parents are not limited geographically in their choice and thus a measure of FDS availability in the municipality may not reflect parents' preferences; however, studies for Chile have found that proximity is an important determinant of school choice, and that most children attend primary school in the municipality they live (Chumacero, Gómez and Paredes 2011), so that access to full day schools in the municipality of residence is an appropriate proxy. One advantage of this measure is that the FDS coverage at the municipal levels is exogenous to each family — whereas actual school choice is not—provided that FDS access at the municipal level is not correlated with families' choice of residency (we discuss migration issues in section 6).

Another relevant aspect of the identification strategy is related to how schools became part of the FDS reform, and thus whether the FDS implementation is distributed randomly over schoolsand therefore municipalities - and time. As indicated previously, each school was allowed to apply to the Ministry of Education for authorization and/or funding to become an FDS school, and after a sorting and selection process, funding was allocated. To our knowledge there is no available data that would allow us to model how schools decided to apply for authorization and funds, neither how the decision making process regarding the allocation of funds was carried out at the Ministry level. Thus, one concern is that since the FDS reform was not randomly implemented, the estimates of its effect might be biased. For instance, schools in a municipality with a disproportionately large fraction of vulnerable students might obtain funding for implementing the FDS reform. At the same time this municipality may also experience poor female labor market outcomes due to poor economic conditions, which in turn increases the vulnerability of its population. In this case, we would observe a negative correlation between FDS access and female labor outcomes.

However, there are two relevant characteristics of the Chilean school system that help our estimation and identification strategy. First, the school system in Chile is highly decentralized, with school districts defined at the municipality level. Each school district is operated in complete independence of other school districts. Second, within each school district principals also operate 
with a high level of decentralization in both the public system (municipal schools) and private subsidized system. Within the public system, principals have gained increasing levels of autonomy (Núñez, Weinstein y Muñoz 2010) and within the private subsidized system, more than 70 percent of schools operate as single standing schools, i.e., they do not operate within a franchise, and therefore the school principal's decisions are not coordinated with other schools-either within the school district or with schools in other school districts (Elacqua, Contreras, Salazar and Santos 2011). The combination of these two characteristics introduce-once all school decisions are aggregated at the municipal level — a large variation in the take up rate across municipalities and time (see previous section); therefore we are confident that in this sense the FDS reform resembles a quasi-natural experiment.

We estimate a reduced-form panel data model of female labor force outcomes. Our identification relies on the assumption that trends in women's labor outcomes across municipalities with different levels of FDS implementation were the same. As indicated previously, Chile's school system dynamics — which are the aggregation of highly independent school decisions — point toward a reasonable plausibility of these assumptions. Additionally, given the criteria in the allocation of public FDS funds, it is unlikely that schools received them in response to changes in the local female labor market. Even though we cannot test these assumptions explicitly our estimates, following the approach in Duflo (2001), we control for pre-existing trends in labor outcomes across municipalities, as well as for other municipality characteristics that can affect labor outcomes and that are independent of FDS implementation. In addition, we implement a panel estimation in which we account for time-invariant individual unobservables, including those that affect both labor outcomes and the choice of residency and the unobserved choice of school.

The panel data model can be described as follows:

$$
L F P_{i m r t}=\theta \mathrm{FDS}_{m r t}+X_{i m r t} \beta+M_{m t} \mu+\alpha_{i}+\gamma_{m}+\tau_{r t}+\omega_{t} D_{m r}+\epsilon_{i m r t}
$$

where the dependent variable $L F P_{\text {imt }}$ is a labor force outcome of woman $i$ living in municipality $m$ and region $r$ in year $t$. We use three different labor force outcomes, which will be described below.

We are interested in the effect of full-day primary schooling on mother's labor force attachment; as parents are able to choose the school for their children, this choice can introduce a 
source of endogeneity. ${ }^{17}$ As explained above, since our data does not specify the school children attend, and in order to minimize the possible endogeneity, we measure the total availability of FDS schools at the local (municipal) level. ${ }^{18}$ The policy variable of interest, FDS $_{m r t}$, measures the share of full-day primary schools in municipality $m$ and region $r$ in year $t$. As mentioned earlier, our identification strategy relies on the gradual and heterogeneous implementation of the policy over time and across municipalities.

Our estimations include time-varying individual characteristics in vector $X_{i m r t}$, and municipality-level characteristics in vector $M_{m r t}$. Given that we are using a panel data set we include an individual-level fixed effect, $\alpha_{i}$, which allows us to control for individual unobserved heterogeneity in the labor participation decisions. Additionally, we include a full set of municipality fixed effects, $\gamma_{m}$, to control for time-invariant omitted factors that affect women's labor supply that are specific to municipalities, such as local labor market conditions, and proximity to labor markets that demand women's labor, among others. Also they control for time-invariant factors that determine FDS access such as location of the municipality, geography, infrastructure costs, among others. We also include region-time fixed effects, $\tau_{t}$, to control for regional trends in labor force outcomes.

In order to account for pre-existing trends in labor force outcomes, we create a categorical variable $D_{m r}$ to classify a municipality as "Low" LFP if its female participation rate in 2003- the year before the first year of our panel—was below the median in that year's distribution, and then include interaction terms of "Low" and year fixed effects in the baseline regressions. This clears the FDS effect of differences in female LFP trends across municipalities that may have been in place prior to the EPS survey. Finally, $\epsilon_{i m r t}$ is an idiosyncratic error term.

The impact of the policy is identified through within-individual changes in coverage of FDS schools over the period we analyze, with changes in FDS occurring at the municipal level. Since our first year of data is 2004, and the policy had been in place for seven years, one might be concerned that it's difficult to detect an effect from the policy if implementation were almost complete. However, Table 2 reveals that in 2004 only 34.7 percent of schools nationwide had adopted full-day

\footnotetext{
${ }^{17}$ Gallego and Hernando (2009) found that the FDS reform did not affect demand for schools, so it is reasonable to propose that the policy is exogenous to mothers' labor force participation decisions.

${ }^{18}$ We can also measure total enrollment under FDS but we believe, that conceptually, parents' choice is affected by the availability of schools under the FDS regime rather than the aggregated availability of FDS slots at the municipality level.
} 
schooling, and Table 3 shows large municipal variation in the level of implementation, leaving scope for identification in our data set.

\section{Data and variables}

Individual information, i.e., labor force participation outcomes $L F P_{i m t}$ and socio-economic characteristics in $X_{i m r t}$, come from Chile's Social Protection Survey, which we denominate as EPS for its Spanish Acronym. ${ }^{19}$ The EPS is the first long-term longitudinal survey implemented in Chile, with several rounds available (years 2002, 2004, 2006, and 2009), whose aim is to collect information for the design of social policies - in particular, for the assessment and reform of the Chilean retirement system. For this purpose, it collects detailed information of respondent's current labor status and labor history, and also information on education, health, household characteristics, and family demographics. We use the last three rounds of the survey (2004, 2006 and 2009) because these are representative at the national level. ${ }^{20}$

Our sample includes women that were potentially affected by the policy, i.e., women with primary school-aged children; additionally, in order to avoid the correlation between women's schooling, retirement, and labor decisions, we include in our sample women aged 25 to 55, leaving us with an unbalanced panel of more than 3,400 women. The panel nature of the data allows us to estimate a model with individual fixed effects to identify the effect of the reform controlling for women's unobservable characteristics, such as attachment to the labor force and/or preferences regarding child care arrangements.

We construct three measures of women's labor force status. First we use a discrete variable that indicates if the woman worked at any time during the year of the survey. ${ }^{21}$ The EPS collects individuals' employment history, which allows us to construct two additional variables that capture longer or degree of permanency in the labor force: a discrete 0-1 variable that indicates whether the woman participated in the labor force more than $50 \%$ of the year of the survey, and a continuous variable that measures the fraction of the year spent in the labor force. The EPS data also allows us

\footnotetext{
19 The survey's name is Encuesta de Protección Social.

${ }^{20}$ We do not use 2002 data because that year's survey was representative of the population that participated in the Social Security system, thus the sample was not representative of women that did not participate in the labor market.

${ }^{21}$ This measure of labor force status is different from other surveys in Chile whose reference periods for labor force participation can be the week, the month or the two months prior to the interview.
} 
to construct measures of women's years of education, whether she is the head of the household, and her age.

The EPS does not report the school that children attend, so in order to construct the policy variable - FDS availability at the municipal level — we obtained administrative school data from the Ministry of Education that contains detailed yearly information on full day enrollment within a school. The program did not require schools to implement full days for all their grade-levels, they were only required to offer it to all classrooms of the same grade, so that schools could progressively increase their full-day enrollment. ${ }^{22}$ Therefore, in order to determine whether a school is participating in the program it is relevant to consider the depth of the implementation within the school in any given year. In this paper, we define a school as an FDS school when the school has its entire grade levels under FDS. Thus our policy variable is the share of schools in a municipality with all grade levels under FDS. ${ }^{23}$

For the municipal-level variables in vector $M_{m r t}$ and $D_{m r}$ we use data from Chile's CASEN Household Surveys to construct variables for municipal characteristics and local labor market conditions. The vector $M_{m r t}$ includes average adult educational attainment, municipal poverty and unemployment rates, and average income per capita in each municipality.

Summary statistics of all variables are found in Table 4. In our sample of mothers aged 25 to 55 years, on average 68.2 percent of women participated in the labor force at some point during the years of the survey. Between 2004 and 2006, labor force participation increased by 6.4 percentage points, from 65.1 percent to 71.5 percent. The decline to 68.2 percent observed in 2009 is explained by the general deterioration of labor market outcomes as Chile entered a recession due to the global financial crisis. Longer-term attachment, measured by the fraction of women that participated in the labor force for six or more months during the year, and percentage of the year that women participated in the labor force, followed similar patterns. They experienced an increase from 62 percent to 66 percent between 2004 and 2006 and remained stable in $2009 .{ }^{24}$

\footnotetext{
${ }^{22}$ For instance, a school offering first to sixth grades, and with two classrooms per grade, could offer FDS for fifth and sixth grade only, provided that both classrooms in each grade were included.

${ }^{23} \mathrm{We}$ also constructed a measure of FDS availability as the fraction of schools that offer at least half their grade levels as FDS. Results were not qualitatively different from the ones reported here and are available upon request.

${ }^{24}$ Pair-wise correlation coefficients between all three outcomes are above 0.9 and significant at a $1 \%$ level. The high correlation between outcomes is a result of the high prevalence of full-time employment in Chile relative to part time employment. There are demand and supply factors in the labor market that can explain this prevalence. Demand factors include asymmetric hiring costs between women and men due to mandated provisions of day-care, and differentiated
} 
Regarding FDS implementation, mothers in our sample live in a municipality where on average 27.4 percent of schools are under the FDS regime. The municipal average share of FDS schools increases consistently over the 2004-2009 period, from 22.8 to 35.5 percent, respectively. A mother's average age is almost 38 years, she has 10.8 years of education completed, and lives in a municipality with a poverty rate of about 15 percent and unemployment rate of 8.9 percent.

\section{Results}

One of the contributions of this paper is the ability to control for women's unobservable characteristics. Thus, before estimating the full model (described previously), we assess the relative importance of each of the different groups of control variables to examine the relative importance of unobservables. The first outcome we analyze is participation in the labor force at any time during the survey year, which we denominate as "Outcome 1." We estimate equation (1) and include only include region-year fixed effects in the regression, to control for heterogeneous time-trends in female LFP across the thirteen administrative regions of the country (Table 5, column 1). With this specification we see that access to full day schools is negatively correlated with mothers' LFP (though not statistically significant), which reflects the evolution of the policy: the first schools to switch to the full day regime were those in smaller, less populated municipalities - which also have lower female labor force participation rates.

In the next specification, we include municipality fixed effects (Table 5, column 2), so that we estimate the effect of increased access to full day schools on mothers' LFP, within municipalities across time. The point estimate reflects a positive correlation between access to full day schools and mothers' participation, revealing that if permanent differences across municipalities are controlled for, an increase in access to full day schools leads to higher participation in the labor market (though the effect is not statistically significant). The latter specification is closer to previous estimates in the literature (with pooled cross section data), and the results in column (2) are similar to the ones reported by Contreras et al. (2010) and Hernando (2009).

In the next specification (Table 5, column 3), we include the full set of individual and timevarying municipal characteristics, finding no significant change in the FDS coefficient. We also find that women with higher levels of education have higher LFP, and that municipal characteristics do

management costs for jobs with shifts. Supply factors include higher relative transport costs for part-time jobs and idiosyncratic preferences of Chilean women over full-time employment (Rau 2010). 
not significantly affect their participation, a result that is not surprising given that we are including municipality fixed effects and that municipal characteristics tend to experience small changes over short periods of time such as the one studied here.

In our next estimation, we control for pre-existing trends in female labor participation (Table 5, column 4). We find similar point estimates to the one observed without pre-existing trends, thus we are confident that the estimated effects of the policy are not driven by pre-existing trends in female labor force participation. ${ }^{25}$

We introduce individual fixed effects in the next four specifications, shown in columns (5) through (8) of Table 5. We repeated the same sequential process of introducing groups of control variables. All these estimations control for time invariant, unobserved individual characteristics, so that they are measuring how the same woman responds to changes in access to FDS schools across time.

We observe that all point estimates increase relative to the same specification without individual fixed effects. Specifically, estimates that control for individual and municipal characteristics as well as for pre-existing trends show that an increase in FDS availability at the municipal level significantly increases labor force participation of women with children in primary school age (Table 5, column 8). The point estimate is more than twice the magnitude of the pooled cross section estimates in column (4), and the effect is more precisely estimated. The other difference between the two sets of estimates (with and without individual FE) is that mother's education is not significant in the individual FE model, which is reasonable because each individual's education level does not vary much beyond age 25 .

Results reported in Table 5 highlight an important contribution of our paper, specifically, that unobservable women's characteristics play an important role in the decision to participate in the labor force - the magnitude of the effect of the policy is much smaller if it is unaccounted for. The decision to engage in the labor market is determined not only by observed characteristics - such as women's education level or local employment opportunities-but also in a significant part by individual factors that are not measured. Accounting for this unobserved heterogeneity yields more accurate estimates of the effect of full-day schooling.

In terms of the magnitude of the impact of the FDS program, using our preferred

\footnotetext{
${ }^{25}$ We also estimated the same regression with an alternative definition for "Low" LFP, were we classify a municipality as "Low" LFP if its female participation rate was below the mean. Results are similar to the ones reported here.
} 
specification which includes all control variables (Table 5, column 8), the point estimate for FDS indicates that if the share of FDS schools in a municipality increases by 1 (or 100 percentage points), then the probability that a woman participates in the labor force would increase by 25 percentage points. To put this result in relevant context, in 2009, about 55 percent of primary schools were FDS (see Table 2), so that an increase of 45 percentage points, i.e., increasing to full FDS coverage, would lead to a predicted increase in female LFP of 11.2 percentage points, or 16 percent. ${ }^{26}$

We also estimated the effect of FDS availability on labor force participation variables that measure more permanent attachment to the labor market: participation for 6 or more months (which we term "Outcome 2") and share of the year worked ("Outcome 3"). In both outcomes we observe a similar pattern regarding the sequential introduction of groups of control variables and individual fixed effect to the one previously described: for both outcomes, point estimates of the FDS effect are larger and more precisely estimated under the fixed effects specification. Since we believe that unobservable characteristics are relevant, we will focus our discussion on our preferred estimates reported in columns (16) and (24) of Table 5.

We find that the effect of higher access to full-day schooling contributes to mothers' attachment to the labor force for longer periods of time. An increase in the share of FDS schools of 45 percentage points leads to an increase in both the probability of women participating in the labor force for at least six months of the year (column 16), as well as the share of the year they work or seek employment (column 24), increase by 17 percentage points, or 26 percent - which is equivalent to two months of work.

Results for these baseline estimates indicate that expansions in the access to schools with longer schedules increases the likelihood that mothers participate in the labor force, revealing that child care for school-aged children is an important determinant of their employment decisions. Furthermore, our results suggest a significantly large effect not only on the probability that mothers engage in the labor force, but also on participating for longer periods. The full-day school policy appears to have long term effects in the sense that it provides women with additional time to devote to longer term, and more stable work.

\footnotetext{
${ }^{26}$ The marginal effect reported is obtained by multiplying the point estimate by 0.45 , and dividing by the average of the dependent variable.
} 


\section{FDS in early grade levels}

We explore whether effects of the policy differ for different grade levels, grouping them according to how the policy affected the number of school hours required, resulting in three categories: $1^{\text {st }}$ and $2^{\text {nd }}$ grades (the reform is optional for these two grades), $3^{\text {rd }}-6^{\text {th }}$ grades, and $7^{\text {th }}-$ $8^{\text {th }}$ grades. By separating FDS access in these three groups we seek to understand whether families respond to the full range of grade levels under FDS, or whether the effect of full-day school access varies with the age of their children, for example, full school days might be useful only when children are very young.

Results for the three outcomes are reported in Table 6 (henceforth we only report results for the full specification). We find access to FDS in $1^{\text {st }}$ and $2^{\text {nd }}$ grade has strong and significant effects on all three outcomes. In the case of labor force participation any time during the year (column 1) we find that moving to universal access to full days in $1^{\text {st }}$ and $2^{\text {nd }}$ grade — or an increase of about 50 percentage points - leads to a predicted increase in female LFP of 18 percentage points (or 26 percent). A similar increase in FDS access leads to increases in longer term attachment of about 45 percent (columns 2 and 3). Access to $3^{\text {rd }}$ through $8^{\text {th }}$ grades that are full day do not have a (statistically) significant impact on any of our measures of labor force outcomes of mothers, which suggests that access to extended school schedules is particularly relevant during early school ages. The effect for FDS on later years diminishes and loses significance. Thus, these results are consistent with the view that FDS is a form of implicit child care, particularly when children are small.

\section{Heterogeneous effects of the FDS policy}

We also estimated heterogeneous effects for different groups of mothers who may respond differently to changes in access to full-day schools. We analyzed whether mothers' age, marital status, being a head of household, education, and presence of preschool children affect decisions with regards to the FDS policy. Younger mothers may respond differently to FDS access because younger cohorts of women are more attached to the work force; thus we create a categorical variable for mothers that were born before or after 1969. ${ }^{27}$ Women that are married (or have a partner) have an additional source of household income, so that they might dedicate less time to the labor market and become less sensitive to changes in FDS access. Mothers who are heads of their household are more attached to the labor market; they are probably more sensitive to changes in FDS access, as

\footnotetext{
${ }^{27}$ We selected 1969 as cut off because in 2009 a mother born in that year would be 40 years old, and age 40 is the middle point between the age limits of our sample (25 to 55 years).
} 
they might benefit more from an extended school schedule that provides formal childcare for their children, facilitating participation in the labor market.

Mothers with more education are more attached to the labor force and have more income; we expect that they are less sensitive to the FDS regime because they would be able to afford alternative childcare arrangements without the policy. We define mothers with high levels of education as those which at least high school completion. Finally, we expect the effect of the FDS policy to be smaller on mothers of primary school aged children with siblings of pre-school age because the FDS reform does not alleviate the child care needs of pre-school children. ${ }^{28}$

We report descriptive statistics of the differences in labor participation outcomes across these five groups of mothers in Table 7, and the differences are in line with our expectations. Mothers who are younger, single, heads of households, more educated, and do not have children in preschool are the groups that have higher labor force participation rates (all differences are statistically significant).

In order to estimate heterogeneous effects across these five groups of mothers, we created a categorical variable (0-1) for each of them and then estimated a fully interacted model. In this fully interacted model, we interact the group's categorical variable with all variables described in equation (1). Results of our estimates by groups are reported in Table 8. For simplicity we only report the estimates for the FDS variable and the interaction term between FDS and the categorical group variable. We also report the p-value of an $\mathrm{F}$ test for joint significance of these two variables.

The estimated impact of the FDS reform on labor force participation at any time during the year is 0.370 for older mothers (Table 8 , column 1) born before 1969, and 0.226 for younger mothers born on or after 1969. The latter point estimate is the sum of the average FDS effect and the interaction term of FDS with the dummy variable for younger women $(0.226=0.370-0.144)$. The effect for older women is statistically significant at the 5\% level whilst the estimated effect for younger women is significant at the $10 \%$ level ( $\mathrm{p}$-value $=0.098)$.

We find that mothers born on or after 1969 have a smaller response to FDS than older mothers, for all three outcomes (Table 8, columns 1 to 3). Older mothers have a response that, is

\footnotetext{
${ }^{28}$ In the last three years of our data (2006-2009), there was an increase in the supply of public child care and preschools through different programs that were independent from (and not coordinated with) the FDS program. Nonetheless, in our section on robustness checks, we perform an exercise to see whether our results are affected by the expansion of child care and preschool centers during this period and find that they are not (see section 6).
} 
about double the magnitude than younger mothers. This is probably due to the fact that younger mothers participate more actively in the labor force (see Table 7), so it is reasonable that increases in FDS would have a larger effect on older mothers who have lower attachment to the labor force and thus more scope to increase their labor force participation.

Contrary to what we had anticipated, our estimates indicate that married mothers (or with a partner) have greater responses to FDS increases (Table 8 , columns 4 to 6). ${ }^{29}$ This is probably explained by the fact that single mothers participate disproportionally more in the labor market than married women (Table 7), thus they experience smaller responses to increases in FDS.

We find similar results for mothers that are heads of household: increases in FDS have a positive effect on women who are head of their household, but the effect on mothers who are not the head of the household is slightly smaller (Table 8, columns 7 to 9). This result is reasonable because due to their position as head of household, mothers are more attached to the labor force so that they are less sensitive to changes in full day school access.

We find that greater access to FDS schools has a positive (statistically significant) effect on labor force participation outcomes of women with low and high education levels, but the impact is twice as large on mothers with lower educational attainment (Table 8, columns 10 to 12). Because of their lower educational attainment, these mothers face tighter financial constraints, so that the formal child care arrangement implicit in the FDS policy alleviates their child care needs more so than more educated mothers with higher incomes and more child care alternatives.

Finally, our estimates indicate that FDS availability has a smaller impact on labor force participation outcomes of mothers with children of pre-school age (Table 8, columns 13 to 15). These results are in line with what we anticipated, since the FDS reform did not extend to children of pre-school age.

\section{Robustness checks}

In this section we perform a series of robustness checks to ensure that our estimates capture a causal effect of the FDS reform on women's labor outcomes and not spurious correlations of the supply of FDS schools across municipalities and over time.

\footnotetext{
${ }^{29}$ The F-test of joint significance reveals that the effect of FDS on single mothers is only significant for outcomes 2 and 3 , i.e., for variables that measure whether the woman worked 6 or more months, and share of the year worked.
} 


\section{Target Population}

As discussed earlier, our results indicate that the FDS policy had a strong impact on the group of women who would most likely benefit from the extended school schedule: mothers with children of primary school age. Similarly, women without children in primary school age should not respond to the FDS policy, and neither should men, since they have a more permanent attachment to the labor force. In Table 9, columns 1 to 6, we report estimates of the effect of FDS availability on the three LFP variables for these two groups — women without primary school-aged children and menand we find that neither of them are affected by the availability of longer school days.

\section{Pre-school Policies}

As described in the Introduction, in 2006 Chile began to implement a large expansion of child care and pre-school centers, affecting children between 3 months and 5 years of age. The child care and pre-school expansion and FDS reforms were independent of each other, implemented by separate public institutions, and were not coordinated. When the pre-school expansion began, the FDS reform had been in place for 9 years. Nonetheless, to rule out the possibility that our estimated results are partially capturing the expansion in pre-school centers, we re-estimated our baseline regressions omitting the last year (2009) from our panel data, so that no overlap of the two policies is present in the estimations. These results are reported in columns 7 to 9 of Table 9; since the sample size falls, standard errors increase, but we observe similar point estimates compared to our baseline regression, so that we are confident that our full results are not capturing the expansion of the preschool system.

\section{School choice in the Chilean Education System}

As described above, one of the features of the Chilean education system is that families can apply to any school of their choice independent of their municipality of residence, ${ }^{30}$ so that availability of FDS schools at the municipality where families live may not be the most precise

\footnotetext{
${ }^{30}$ Private subsidized schools were able to select students and charge fees during the 2004-2009 period, whereas municipal schools could not, so that in the Chilean education system there is incomplete school choice: familes can apply to any school within their financial constraints, and within those they are limited by the school's selection processes.
} 
measure for access to full day schooling. And even though families tend to choose schools close to their homes (Chumacero, Gómez and Paredes, 2011), that choice set may include schools in other bordering municipalities.

To clean our results from capturing neighboring municipality information, we exclude from our estimates the three main metropolitan areas in the country where inter-municipal commuting is more common. These metropolitan areas are urban, closely located, and densely populated, so that it is more likely that parents cross municipal lines in their choice of school. The three main metropolitan areas we exclude are Santiago, Valparaiso, and Concepcion and they represent about 50 percent of our sample. ${ }^{31}$ We find that our results remain basically unchanged (Table 9, columns 10 to 12 ) and are more precisely estimated. This is probably because, as it has been documented in other studies, most children study at the closest school from home, and our results suggest that most children don't cross municipal lines to attend primary school.

\section{Migration}

Another concern with our results is the possibility that they are driven by migration decisions correlated with the implementation of FDS. For instance, it is feasible that families migrate from municipalities with low levels of FDS implementation towards those with high levels of FDS to facilitate mothers' labor force participation. Thus, if this were the case, our positive estimates would not be measuring the true effect of FDS but instead they would be capturing the self-selection of mothers with a high propensity to work into municipalities with higher FDS implementation.

To have a sense of how important migration is, in our sample 12 percent of mothers migrated to a different municipality between 2004 and 2006, and migration decreased to 8.7 percent between 2006 and 2009 One interesting property of migration in this period is that about 80 percent of migration is intraregional, thus, families engage in short distance migration to municipalities with similar characteristics.

Even though migration is not a widespread phenomenon in Chile, we analyze whether the FDS implementation had an effect on families' migration decision to assess whether our estimates are affected by self-selection. For this we estimate a model of the determinants of the probability of

\footnotetext{
${ }^{31}$ In the Santiago metropolitan area, we excluded all municipalities in the XIII region. In the Valparaiso metropolitan area we excluded the following municipalities: Valparaiso, Viña del Mar, Con-Con, Quilpué and Villa Alemana. In the Concepcion metropolitan area we excluded Concepcion, Talcahuano, Sand Pedro de la Paz, Hualpen and Penco.
} 
migration at the individual level, following the approach in Borjas et al. (1992). We construct a categorical variable that takes the value of one if the mother in our sample moved to a different municipality during the years in which she was surveyed, which is the dependent variable for the empirical model. We estimate a regression of the determinants of migration in our sample, controlling for mothers' individual characteristics (years of education, whether she has spouse/partner, whether she is the head of the household, and age and age squared), as well as for municipality characteristics in the municipality of origin (where mothers were living in the previous survey year) and in the municipality of destination (where mothers lived in the year of the survey). We are particularly interested in knowing whether FDS differences across municipalities affect location decisions.

Results are reported in Table 10. The first column reports results for a model with municipal fixed effects but without individual fixed effects, thus akin to a pooled cross-section estimate. They indicate that more educated mothers as well as mothers that are heads of the household tend to migrate more. This could be because more educated women may experience more employment opportunities across the country. At the same time, mothers that are heads of the household are more attached to the labor market and will be more likely to accept employment opportunities that appear in other locations. FDS access does not affect migration decisions in Chile.

In column 2 we report results when we control for individual fixed effects. We find that both education and head of the household are no longer significant when individual unboservables are taken into account, and FDS access remains unimportant in migration decisions. This exercise supports our identification strategy, as it reveals that families are not self-selecting into municipalities with higher access to FDS.

\section{Conclusions}

This paper analyzed a national school reform in Chile that lengthened the school day from half to full day schedules, and the effect it had on labor force participation outcomes of mothers most affected by the policy, i.e., those with children in primary school. We identify the effect of the policy from its quasi-experimental implementation using a panel data set. We find that increased availability of FDS primary schools in the municipality significantly increases the likelihood that mothers participate in the labor force. If the supply of primary schools were to increase by 45 percentage points - similar to moving to full FDS coverage - mothers' LFP would increase by 
almost 11.9 percentage points. This is a large increase, considering the country's low levels of women's participation in the labor force. Universal coverage of full-day schools would also increase more permanent labor force attachment by about 18 percentage points, suggesting that provision of child care arrangements for school-age children can facilitate more stable employment for women.

Another relevant finding is that the results are driven by accessibility to full day schedules in $1^{\text {st }}$ and $2^{\text {nd }}$ grades. This suggests that mothers are mostly constrained when children are relatively young. This result is especially interesting because the provision of FDS in $1^{\text {st }}$ and $2^{\text {nd }}$ grade is not mandated by the reform, and it suggests that increasing access to FDS in these early levels would have the strongest impact on fostering female labor force participation. Therefore, our results suggest that authorities should prioritize expansion in those two grade levels.

We also find that there are heterogeneous effects of the policy among different groups of women: older mothers, mothers that have a spouse/partner, and mothers without pre-school aged children experience larger responses to changes in FDS supply at the municipal level. Furthermore, the policy has a greater impact on mothers with lower educational attainment, who probably have lower incomes, so that the positive effects of the FDS policy appear to benefit more vulnerable women.

Our results are consistent with others in the literature that find positive effects of child care expansion for pre-school children on mothers' labor decisions. Additionally, our findings suggest that lack of child care not only limits participation but also the quality of jobs that mothers can access - at least as measured by attachment and length of employment. Several countries in the Latin American region are contemplating measures similar to this reform-longer school schedules, and after-school programs. Our findings suggest that such policies can increase women's employment in the region. 


\section{References}

Baker, Michael, Jonathan Gruber, Kevin Milligan. 2008. Universal child care, maternal labor supply, and family well-being. Journal of Political Economy 116(4):709-45.

Bellei, Cristián. 2009. Does lengthening the school day increase students' academic achievement? Results from a natural experiment in Chile. Economics of Education Review 28(5):629-40.

Berlinski Samuel, Sebastian Galiani. 2007. The effect of a large expansion of pre-primary school facilities on preschool attendance and maternal employment. Labour Economics 14(3):66580 .

Berthelon, Matias, Diana Kruger. 2011. Risky behavior among youth: Incapacitation effects of school on adolescent motherhood and crime in Chile. Journal of Public Economics 95:41-53.

Blau, David, Janet Currie. 2006. Pre-school, day care, and after-school care: who's minding the kids? In Handbook of the Economics of Education Vol. 2, chapter 20, 1163-278, Elsevier.

Blau, David M., Philip K. Robins.1988. Child care costs and family labor supply. Review of Economics and Statistics 70(3):374-81.

Blau, Francine D., Lawrence M. Kahn. 2013. Female labor supply: why is the U.S. falling behind? Working Paper no.18702, National Bureau of Economic Research, Cambridge, MA.

Borjas, George J., Stephen G. Bronars, Stephen J. Trejo. 1992. Self-selection and internal migration in the United States. Journal of Urban Economics 32(2): 159-185.

Cascio, Elizabeth U. 2009. Maternal labor supply and the introduction of kindergartens into American public schools. The Journal of Human Resources 44(1):140-70.

Chumacero, Rómulo A., Daniel Gómez, Ricardo Paredes. 2011. I would walk 500 miles (if it paid): vouchers and school choice in Chile. Economics of Education Review 30(5):1103-14.

Contreras, Dante, Paulina Sepúlveda, Soledad Cabrera. 2010. The effects of lengthening the school day on female labor supply: evidence from a quasi-experiment in Chile. Working Paper Num. 323. University of Chile, Department of Economics.

Del Boca, Daniela. 2002. The effect of child care and part time opportunities on participation and fertility decisions in Italy. Journal of Population Economics 15(3):549-573.

Duflo, Esther. 2001. Schooling and labor market consequences of school construction in Indonesia: evidence from an unusual policy experiment. American Economic Review 91(4): 795-13.

Elacqua, Gregory, Dante Contreras, Felipe Salazar, Humberto Santos. 2011. The effectiveness of private school franchises in Chile's national voucher program. School Effectiveness and School Improvement 22(3):1-42. 
Fitzpatrick, Maria D. 2012. Revising our thinking about the relationship between maternal labor supply and preschool. The Journal of Human Resources Economics 47(3):583-612.

Fitzpatrick, Maria D. 2010. Preschoolers enrolled and mothers at work? The effects of universal prekindergarten. Journal of Labor Economics 28(1):51-85.

Gallego, Francisco, Andrés Hernando. 2009. School choice in Chile: looking at the demand side. Working Paper Num. 356. Instituto de Economía, Pontificia Universidad Católica de Chile.

García-Huidobro, Juan, Carlos Concha. 2009. Jornada Escolar Completa: la Experiencia Chilena. Unpublished manuscript, Pontificia Universidad Católica de Chile.

Gelbach, J. 2002. Public schooling for young children and maternal labor supply. American Economic Review 92(1): 307-22.

Hernando, Andrés. 2009. Female labor participation and child care in Chile: A natural experiment. Unpublished manuscript. Universidad Adolfo Ibáñez.

Lefebvre, Pierre, Philip Merrigan. 2008. Child-care policy and the labor supply of mothers with young children: A natural experiment from Canada. Journal of Labor Economics 26(3):51948.

Lokshin, Michael. 2004. Household child care choices and women's work behavior in Russia. The Journal of Human Resources 39(4):1094-115.

Mizala, Alejandra, Pilar Romaguera. 2000. School performance and choice: the Chilean experience. The Journal of Human Resources 35(2):392-417.

Núñez, Iván, José Weinstein, Gonzalo Muñoz. 2010. ¿Posición olvidada? Una mirada desde la normativa a la historia de la dirección escolar en chile. Psicoperspectivas 9(2):53-81.

Pires, Tiago, Sergio Urzua. 2014. Longer School Days, Better Outcomes? Unpublished manuscript, University of Maryland.

Powell, Lisa M. 2002. Joint labor supply and child care choice decisions of married mothers. The Journal of Human Resources 37(1):106-28.

Rau, Tomás. 2010. El trabajo de tiempo parcial en Chile. Economía Chilena 13(1):39-59.

Subsecretaría de Previsión Social, Encuesta de Protección Social, Chile. http://www.previsionsocial.gob.cl/subprev/?page_id=7185 
Figure 1

Primary school enrollment 1990-2009

By length of school day (millions of students)

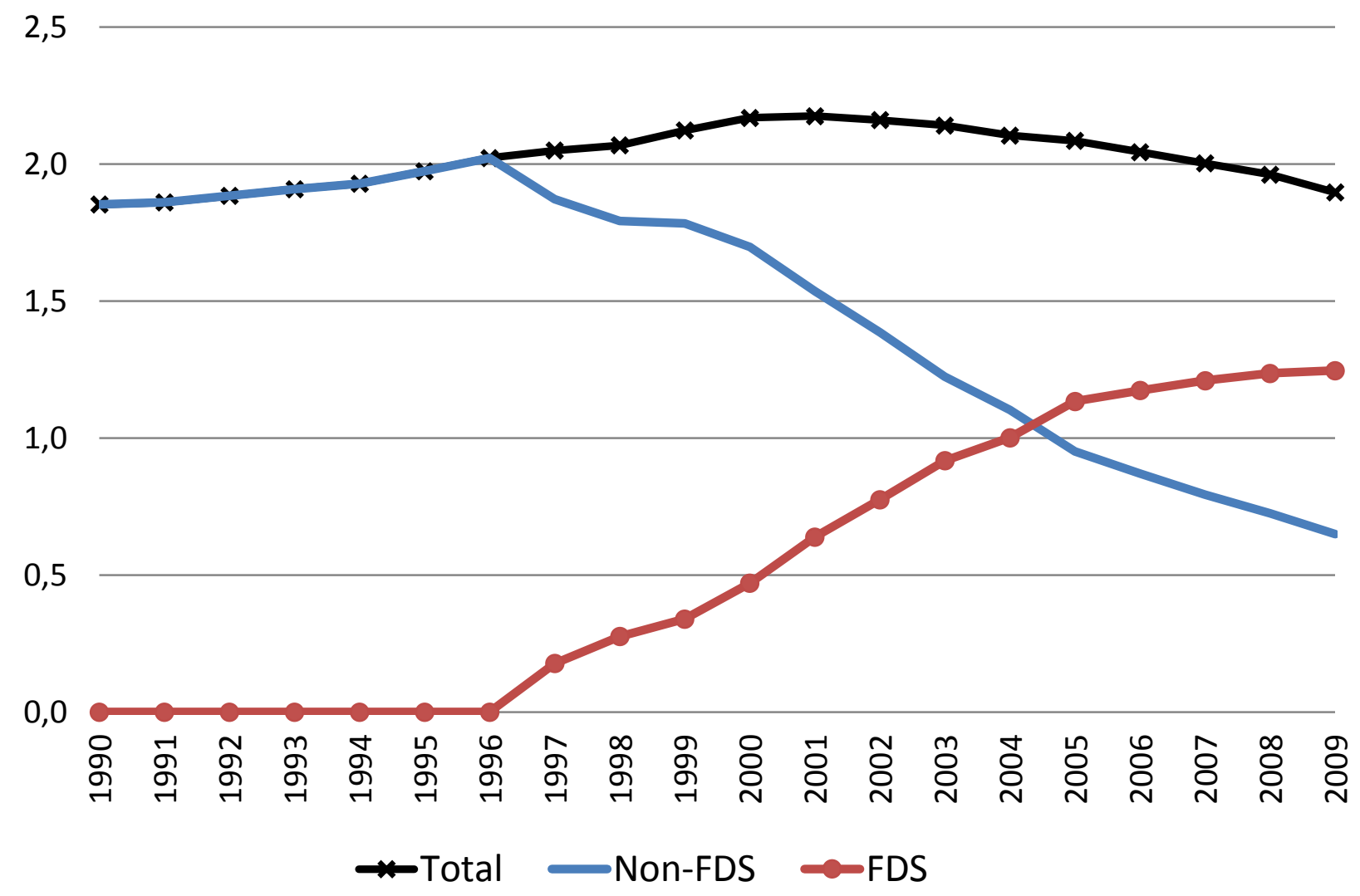

Source: Authors' estimates based School Directory/Administrative JEC data (MINEDUC). 
Figure 2

Evolution of Municipal Share of Primary schools under FDS regime, 2004-2009 (Fraction of total number of schools within municipalities)

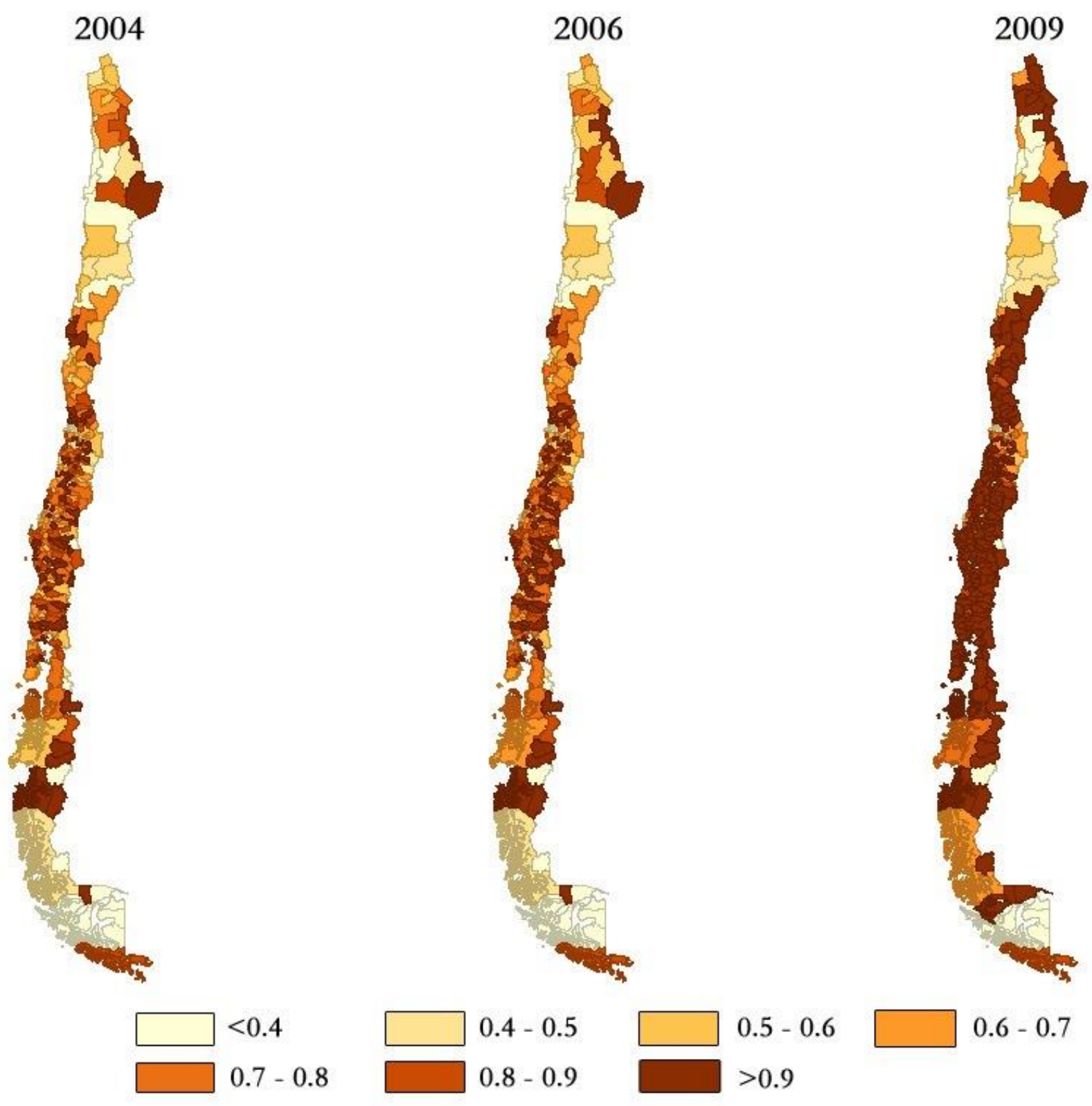

Source: Authors' estimates based School Directory/Administrative JEC data (MINEDUC). 


\section{Table 1}

Main reason mothers do not participate in labor force

\begin{tabular}{|c|c|c|c|}
\hline \multirow[b]{2}{*}{ Reason } & \multicolumn{3}{|c|}{ Mother whose youngest child is of: } \\
\hline & $\begin{array}{c}\text { Pre-school } \\
\text { age }\end{array}$ & $\begin{array}{c}\text { Primary } \\
\text { school age }\end{array}$ & $\begin{array}{l}\text { Secondary } \\
\text { school age }\end{array}$ \\
\hline Household chores & $37 \%$ & $54 \%$ & $63 \%$ \\
\hline Lack of child care & $48 \%$ & $24 \%$ & $4 \%$ \\
\hline Student & $1 \%$ & $1 \%$ & $1 \%$ \\
\hline Not interested & $3 \%$ & $4 \%$ & $1 \%$ \\
\hline Other reasons & $10 \%$ & $17 \%$ & $32 \%$ \\
\hline Total & $100 \%$ & $100 \%$ & $100 \%$ \\
\hline Observations & 369,263 & 383,854 & 202,616 \\
\hline
\end{tabular}


Table 2

Primary schools under FDS regime, 1997-2009 (\% of total number of schools), by Region

\begin{tabular}{|c|c|c|c|c|c|c|c|c|c|c|c|c|c|c|}
\hline Region & 1997 & 1998 & 1999 & 2000 & 2001 & 2002 & 2003 & 2004 & 2005 & 2006 & 2007 & 2008 & 2009 & $\begin{array}{c}\text { Primary } \\
\text { Enrollment in } \\
1997 \\
\text { (\% total) }\end{array}$ \\
\hline 1 & 9.1 & 14.1 & 13.8 & 15.7 & 16.1 & 17.6 & 18.8 & 18.2 & 18.3 & 19.2 & 19.3 & 21.2 & 47.1 & $3 \%$ \\
\hline II & 8.7 & 9.3 & 10.4 & 11.1 & 11.8 & 13.8 & 13.4 & 13.3 & 15.1 & 14.9 & 14.4 & 14.3 & 20.0 & $3 \%$ \\
\hline III & 17.5 & 18.2 & 18.5 & 18.5 & 22.0 & 23.6 & 23.2 & 24.3 & 22.0 & 24.3 & 27.6 & 27.8 & 39.1 & $2 \%$ \\
\hline IV & 13.1 & 15.8 & 18.5 & 20.6 & 23.1 & 28.9 & 33.7 & 33.2 & 34.1 & 33.9 & 35.9 & 36.5 & 58.4 & $4 \%$ \\
\hline V & 13.3 & 17.3 & 21.3 & 23.7 & 25.8 & 27.4 & 28.3 & 28.9 & 28.7 & 29.7 & 30.8 & 32.5 & 37.4 & $10 \%$ \\
\hline VI & 13.7 & 18.3 & 18.6 & 22.5 & 28.0 & 32.3 & 34.8 & 38.1 & 40.9 & 42.1 & 44.5 & 45.9 & 57.8 & $5 \%$ \\
\hline VII & 13.4 & 17.7 & 19.1 & 22.3 & 25.9 & 32.5 & 36.0 & 40.7 & 41.3 & 43.6 & 46.9 & 50.3 & 69.1 & $7 \%$ \\
\hline VIII & 13.1 & 16.6 & 19.5 & 23.4 & 29.0 & 34.0 & 35.5 & 37.8 & 39.8 & 42.7 & 43.7 & 44.7 & 60.3 & $13 \%$ \\
\hline IX & 29.5 & 34.3 & 39.2 & 43.0 & 45.6 & 48.5 & 50.1 & 51.5 & 52.5 & 54.5 & 56.1 & 57.9 & 82.1 & $7 \%$ \\
\hline$x$ & 30.8 & 36.7 & 37.3 & 39.3 & 41.2 & 41.6 & 43.6 & 44.7 & 47.2 & 49.3 & 50.8 & 51.9 & 80.6 & $8 \%$ \\
\hline$X I$ & 21.4 & 29.8 & 35.6 & 40.0 & 45.8 & 46.8 & 49.3 & 50.7 & 50.7 & 52.2 & 55.9 & 53.7 & 65.7 & $1 \%$ \\
\hline XII & 3.9 & 6.0 & 6.1 & 6.3 & 5.8 & 5.7 & 5.8 & 5.8 & 5.8 & 5.6 & 9.3 & 7.3 & 20.0 & $1 \%$ \\
\hline XIII & 4.3 & 5.6 & 7.1 & 9.0 & 12.3 & 12.8 & 14.2 & 14.6 & 15.9 & 16.6 & 17.3 & 17.9 & 20.0 & $36 \%$ \\
\hline Regional Av. & 14.8 & 18.4 & 20.4 & 22.7 & 25.6 & 28.1 & 29.7 & 30.9 & 31.7 & 33.0 & 34.8 & 35.5 & 50.6 & $100 \%$ \\
\hline National total & 17.0 & 20.7 & 23.0 & 25.8 & 29.0 & 31.8 & 33.5 & 34.7 & 35.9 & 37.4 & 38.8 & 39.9 & 55.6 & $100 \%$ \\
\hline
\end{tabular}

Source: Authors' estimates from administrative data, Ministry of Education. Share of schools with at all their grade levels under the FDS regime. Includes schools that receive public funds (municipal and voucher schools, represent 92\% of total enrollment nationwide). Primary enrollment shares by region are shown only for 1997 as they remain relatively constant across the period. Years shadowed are those included in our estimates. Santiago, the capital city, is located in the XIII region. 


\section{Table 3}

Percentage of municipalities by share of FDS implementation, 1997-2009.

\section{Share of schools within}

municipality under FDS

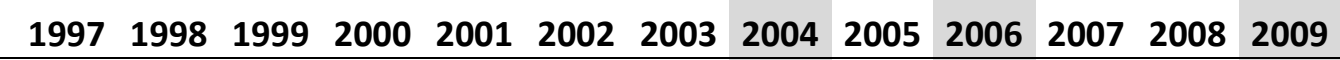

\begin{tabular}{crrrrrrrrrrr|r|r|r}
\hline $0-9$ & 38.0 & 29.9 & 26.0 & 21.6 & 17.1 & 14.7 & 12.6 & 11.7 & 10.2 & 9.9 & 9.6 & 9.3 & 6.9 \\
$10-19$ & 23.7 & 21.0 & 18.0 & 17.4 & 12.9 & 8.7 & 9.6 & 8.1 & 9.0 & 8.4 & 7.8 & 8.1 & 6.9 \\
$20-29$ & 12.9 & 15.3 & 17.4 & 17.1 & 16.2 & 14.4 & 9.9 & 12.9 & 12.3 & 9.3 & 8.7 & 8.1 & 3.0 \\
$30-39$ & 10.2 & 13.5 & 9.3 & 10.8 & 13.2 & 14.4 & 18.6 & 14.4 & 9.9 & 12.0 & 12.0 & 10.7 & 7.2 \\
$40-49$ & 4.2 & 7.8 & 10.8 & 10.8 & 13.2 & 12.9 & 12.6 & 12.3 & 12.3 & 12.3 & 11.1 & 12.8 & 3.0 \\
$50-59$ & 1.5 & 2.1 & 5.1 & 6.3 & 6.6 & 9.0 & 8.4 & 9.3 & 11.4 & 10.5 & 12.0 & 11.9 & 5.7 \\
$60-69$ & 1.2 & 1.2 & 1.8 & 2.4 & 4.2 & 5.4 & 8.1 & 7.5 & 7.2 & 9.0 & 10.2 & 11.0 & 7.2 \\
$70-79$ & 0.3 & 0.6 & 0.6 & 1.5 & 3.0 & 3.3 & 4.8 & 5.4 & 6.3 & 6.0 & 8.4 & 8.4 & 13.4 \\
$80-89$ & 0.0 & 0.0 & 0.0 & 0.0 & 0.3 & 0.3 & 0.6 & 1.2 & 1.5 & 2.7 & 2.4 & 3.9 & 18.2 \\
$90-100$ & 8.1 & 8.7 & 11.1 & 12.3 & 13.5 & 17.1 & 15.0 & 17.4 & 20.1 & 20.1 & 18.0 & 15.8 & 28.7 \\
\hline & 100 & 100 & 100 & 100 & 100 & 100 & 100 & 100 & 100 & 100 & 100 & 100 & 100 \\
\hline Number of municipalities & 334 & 334 & 334 & 334 & 334 & 334 & 334 & 334 & 334 & 334 & 334 & 335 & 335 \\
\hline
\end{tabular}

Source: Authors' estimates from administrative data, Ministry of Education. Includes schools that receive public funds

(municipal and voucher schools, represent 92\% of total enrollment nationwide). Years shadowed are those included in our estimates. 
Table 4

Summary statistics: mean and standard deviations

\begin{tabular}{|c|c|c|c|c|}
\hline Variable & 2004 & 2006 & 2009 & $\begin{array}{c}\text { Average } \\
2004-2009\end{array}$ \\
\hline \multicolumn{5}{|l|}{ Dependent variable } \\
\hline \multirow[t]{2}{*}{ Participation in LF at any time } & 0.651 & 0.715 & 0.682 & 0.682 \\
\hline & $(0.48)$ & $(0.45)$ & $(0.47)$ & $(0.47)$ \\
\hline \multirow[t]{2}{*}{ Participation in LF for $6+$ months of year } & 0.621 & 0.662 & 0.664 & 0.648 \\
\hline & $(0.49)$ & $(0.47)$ & $(0.47)$ & $(0.48)$ \\
\hline \multirow[t]{2}{*}{ Participation in LF, fraction of year } & 0.622 & 0.660 & 0.661 & 0.647 \\
\hline & $(0.48)$ & $(0.46)$ & $(0.46)$ & $(0.47)$ \\
\hline \multicolumn{5}{|l|}{ Policy variable } \\
\hline \multirow[t]{2}{*}{ Share FDS schools at Municipality } & 0.228 & 0.252 & 0.356 & 0.274 \\
\hline & $(0.19)$ & $(0.19)$ & $(0.26)$ & $(0.22)$ \\
\hline \multicolumn{5}{|l|}{ Individual characteristics } \\
\hline \multirow[t]{2}{*}{ Years schooling } & 10.5 & 10.8 & 11.0 & 10.8 \\
\hline & (3.4) & (3.4) & (3.2) & (3.4) \\
\hline \multirow[t]{2}{*}{ Age } & 37.6 & 37.8 & 38.4 & 37.9 \\
\hline & (6.6) & (6.7) & (6.6) & (6.6) \\
\hline \multicolumn{5}{|l|}{ Municipality characteristics } \\
\hline \multirow[t]{2}{*}{ Average schooling } & 10.0 & 10.0 & 10.1 & 10.0 \\
\hline & $(1.3)$ & $(1.2)$ & (1.1) & $(1.2)$ \\
\hline \multirow[t]{2}{*}{ Poverty rate } & 0.168 & 0.138 & 0.158 & 0.155 \\
\hline & $(0.07)$ & $(0.06)$ & $(0.07)$ & $(0.07)$ \\
\hline \multirow[t]{2}{*}{ Unemployment rate } & 0.089 & 0.075 & 0.106 & 0.089 \\
\hline & $(0.025)$ & $(0.025)$ & $(0.029)$ & $(0.029)$ \\
\hline Num. of observations & 2,337 & 2,231 & 1,885 & 6,453 \\
\hline Num. of women in panel & \multicolumn{4}{|c|}{3,350} \\
\hline
\end{tabular}

Source: EPS panel (2004-2009), CASEN surveys, and administrative data from the Ministry of Education. Standard deviations in parentheses. Sample includes women aged 25 to 55, who had school aged children when they were surveyed. Share of FDS schools at municipality level is the fraction of schools with at all their grade levels under the FDS regime. 
Table 5

Effect of Full-Day Schooling at the Municipal level on female labor outcomes

\begin{tabular}{|c|c|c|c|c|c|c|c|c|}
\hline \multirow[b]{3}{*}{ VARIABLES } & \multicolumn{8}{|c|}{ Outcome 1: Participated in LF any time during the year } \\
\hline & \multicolumn{4}{|c|}{ No Individual FE } & \multicolumn{4}{|c|}{ Individual FE } \\
\hline & $(1)$ & $(2)$ & (3) & $(4)$ & $(5)$ & $(6)$ & (7) & $(8)$ \\
\hline \multirow[t]{2}{*}{ Share of FDS schools in Municipality } & -0.0334 & 0.113 & 0.110 & 0.0978 & 0.0228 & 0.201 & $0.240 *$ & $0.265^{*}$ \\
\hline & $(0.0494)$ & $(0.132)$ & $(0.135)$ & $(0.144)$ & $(0.0894)$ & $(0.146)$ & $(0.144)$ & $(0.156)$ \\
\hline \multirow[t]{2}{*}{ Years of schooling completed } & & & $0.0265 * * *$ & $0.0266 * * *$ & & & 0.00571 & 0.00595 \\
\hline & & & $(0.00216)$ & $(0.00216)$ & & & $(0.00543)$ & $(0.00545)$ \\
\hline \multirow[t]{2}{*}{ Age } & & & 0.0103 & 0.00975 & & & -0.0174 & -0.0160 \\
\hline & & & $(0.0103)$ & $(0.0103)$ & & & $(0.0224)$ & $(0.0223)$ \\
\hline \multirow[t]{2}{*}{ Age-squared } & & & -0.000175 & -0.000166 & & & -0.000200 & -0.000201 \\
\hline & & & $(0.000131)$ & $(0.000132)$ & & & $(0.000248)$ & $(0.000250)$ \\
\hline \multirow[t]{2}{*}{ Municipal ave. school attainment } & & & -0.0105 & -0.00719 & & & $-0.0503 *$ & -0.0430 \\
\hline & & & $(0.0250)$ & $(0.0252)$ & & & $(0.0296)$ & $(0.0300)$ \\
\hline \multirow[t]{2}{*}{ Municipal poverty rate } & & & 0.187 & 0.196 & & & 0.00308 & -0.0121 \\
\hline & & & $(0.197)$ & $(0.200)$ & & & $(0.191)$ & $(0.204)$ \\
\hline \multirow[t]{2}{*}{ Municipal unemployment rate } & & & -0.166 & -0.118 & & & -0.219 & -0.142 \\
\hline & & & $(0.415)$ & $(0.418)$ & & & $(0.441)$ & $(0.437)$ \\
\hline Region-year fixed effects & YES & YES & YES & YES & YES & YES & YES & YES \\
\hline Municipal fixed effects & NO & YES & YES & YES & NO & YES & YES & YES \\
\hline Individual characteristics & NO & NO & YES & YES & NO & NO & YES & YES \\
\hline Pre-existing LFP trends & NO & NO & NO & YES & NO & NO & NO & YES \\
\hline Individual fixed effects & NO & NO & NO & NO & YES & YES & YES & YES \\
\hline Observations & 6,537 & 6,537 & 6,480 & 6,453 & 6,537 & 6,537 & 6,480 & 6,453 \\
\hline R-squared & 0.011 & 0.065 & 0.101 & 0.099 & 0.029 & 0.068 & 0.074 & 0.074 \\
\hline Mean-Dependent Variable & 0.681 & 0.681 & 0.682 & 0.682 & 0.681 & 0.681 & 0.682 & 0.682 \\
\hline Num. of women in panel & & & & & 3,373 & 3,373 & 3,361 & 3,350 \\
\hline
\end{tabular}

Data from EPS survey, year 2004, 2006 and 2009. Women aged 25 to 55, who had school aged children when they were surveyed. Share of FDS schools is the fraction of schools with at all their grade levels under the FDS regime. Robust standard errors, clustered at the municipal level, in parentheses. ***, **, * reflect statistical significance at $1 \%, 5 \%$ and $10 \%$ levels, respectively. Not shown: region-year fixed effects, municipality fixed effects, interactions between a categorical variable for pre 2004 female labor force participation and year fixed effects, and individual fixed effects. 
Table 5 (continued)

Effect of Full-Day Schooling at the Municipal level on female labor outcomes

\begin{tabular}{|c|c|c|c|c|c|c|c|c|}
\hline \multirow[b]{3}{*}{ VARIABLES } & \multicolumn{8}{|c|}{ Outcome 2: Participated in LF for $6+$ months during the year } \\
\hline & \multicolumn{4}{|c|}{ No Individual FE } & \multicolumn{4}{|c|}{ Individual FE } \\
\hline & (9) & (10) & $(11)$ & $(12)$ & $(13)$ & $(14)$ & $(15)$ & (16) \\
\hline \multirow[t]{2}{*}{ Share of FDS schools in Municipality } & -0.0327 & $0.278 *$ & $0.280^{*}$ & $0.292^{*}$ & 0.128 & $0.326 *$ & $0.384 * *$ & $0.418^{* *}$ \\
\hline & $(0.0475)$ & $(0.165)$ & $(0.163)$ & $(0.172)$ & $(0.106)$ & $(0.184)$ & $(0.179)$ & $(0.182)$ \\
\hline \multirow[t]{2}{*}{ Years of schooling completed } & & & $0.0287 * * *$ & $0.0287 * * *$ & & & 0.00452 & 0.00482 \\
\hline & & & $(0.00202)$ & $(0.00202)$ & & & $(0.00584)$ & $(0.00584)$ \\
\hline \multirow[t]{2}{*}{ Age } & & & 0.0107 & 0.0102 & & & -0.00505 & -0.00296 \\
\hline & & & $(0.0105)$ & $(0.0105)$ & & & $(0.0243)$ & $(0.0243)$ \\
\hline \multirow[t]{2}{*}{ Age-squared } & & & -0.000166 & -0.000158 & & & -0.000272 & -0.000270 \\
\hline & & & $(0.000135)$ & $(0.000135)$ & & & $(0.000269)$ & $(0.000273)$ \\
\hline \multirow[t]{2}{*}{ Municipal ave. school attainment } & & & 0.0258 & 0.0333 & & & -0.0190 & -0.00877 \\
\hline & & & $(0.0246)$ & $(0.0248)$ & & & $(0.0294)$ & $(0.0295)$ \\
\hline \multirow[t]{2}{*}{ Municipal poverty rate } & & & 0.296 & 0.292 & & & 0.0753 & 0.0691 \\
\hline & & & $(0.214)$ & $(0.217)$ & & & $(0.202)$ & $(0.213)$ \\
\hline \multirow[t]{2}{*}{ Municipal unemployment rate } & & & -0.440 & -0.372 & & & -0.641 & -0.547 \\
\hline & & & $(0.424)$ & $(0.422)$ & & & $(0.461)$ & $(0.457)$ \\
\hline Region-year fixed effects & YES & YES & YES & YES & YES & YES & YES & YES \\
\hline Municipal fixed effects & NO & YES & YES & YES & NO & YES & YES & YES \\
\hline Individual characteristics & NO & NO & YES & YES & NO & NO & YES & YES \\
\hline Pre-existing LFP trends & NO & NO & NO & YES & NO & NO & NO & YES \\
\hline Individual fixed effects & NO & NO & NO & NO & YES & YES & YES & YES \\
\hline Observations & 6,537 & 6,537 & 6,480 & 6,453 & 6,537 & 6,537 & 6,480 & 6,453 \\
\hline R-squared & 0.009 & 0.059 & 0.097 & 0.096 & 0.024 & 0.062 & 0.067 & 0.066 \\
\hline Mean-Dependent Variable & 0.647 & 0.647 & 0.647 & 0.648 & 0.647 & 0.647 & 0.647 & 0.648 \\
\hline Num. of women in panel & & & & & 3,373 & 3,373 & 3,361 & 3,350 \\
\hline
\end{tabular}

Data from EPS survey, year 2004, 2006 and 2009. Women aged 25 to 55, who had school aged children when they were surveyed. Share of FDS schools is the fraction of schools with at all their grade levels under the FDS regime. Robust standard errors, clustered at the municipal level, in parentheses. ***, **, * reflect statistical significance at $1 \%, 5 \%$ and $10 \%$ levels, respectively. Not shown: region-year fixed effects, municipality fixed effects, interactions between a categorical variable for pre 2004 female labor force participation and year fixed effects, and individual fixed effects. 
Table 5 (continued)

Effect of Full-Day Schooling at the Municipal level on female labor outcomes

\begin{tabular}{|c|c|c|c|c|c|c|c|c|}
\hline \multirow[b]{3}{*}{ VARIABLES } & \multicolumn{8}{|c|}{ Outcome 3: Fraction of year in which participated in LF } \\
\hline & \multicolumn{4}{|c|}{ No Individual FE } & \multicolumn{4}{|c|}{ Individual FE } \\
\hline & $(17)$ & $(18)$ & (19) & $(20)$ & $(21)$ & $(22)$ & $(23)$ & $(24)$ \\
\hline \multirow[t]{2}{*}{ Share of FDS schools in Municipality } & -0.0349 & 0.252 & 0.257 & 0.263 & 0.125 & $0.321 *$ & $0.378 * *$ & $0.405^{* *}$ \\
\hline & $(0.0468)$ & $(0.159)$ & (0.158) & $(0.165)$ & (0.103) & $(0.177)$ & $(0.173)$ & $(0.176)$ \\
\hline \multirow[t]{2}{*}{ Years of schooling completed } & & & $0.0293 * * *$ & $0.0293 * * *$ & & & 0.00622 & 0.00654 \\
\hline & & & $(0.00203)$ & $(0.00202)$ & & & $(0.00560)$ & $(0.00561)$ \\
\hline \multirow[t]{2}{*}{ Age } & & & 0.0100 & 0.00952 & & & -0.00656 & -0.00453 \\
\hline & & & $(0.0102)$ & $(0.0102)$ & & & $(0.0233)$ & $(0.0232)$ \\
\hline \multirow[t]{2}{*}{ Age-squared } & & & -0.000156 & -0.000149 & & & -0.000238 & -0.000237 \\
\hline & & & $(0.000130)$ & $(0.000130)$ & & & $(0.000257)$ & $(0.000261)$ \\
\hline \multirow[t]{2}{*}{ Municipal ave. school attainment } & & & 0.0219 & 0.0285 & & & -0.0215 & -0.0125 \\
\hline & & & $(0.0240)$ & $(0.0241)$ & & & $(0.0288)$ & $(0.0287)$ \\
\hline \multirow[t]{2}{*}{ Municipal poverty rate } & & & 0.316 & 0.314 & & & 0.0970 & 0.0863 \\
\hline & & & $(0.213)$ & $(0.216)$ & & & $(0.194)$ & $(0.205)$ \\
\hline \multirow[t]{2}{*}{ Municipal unemployment rate } & & & -0.459 & -0.391 & & & -0.666 & -0.573 \\
\hline & & & $(0.421)$ & $(0.420)$ & & & $(0.447)$ & $(0.443)$ \\
\hline Region-year fixed effects & YES & YES & YES & YES & YES & YES & YES & YES \\
\hline Municipal fixed effects & NO & YES & YES & YES & NO & YES & YES & YES \\
\hline Individual characteristics & NO & NO & YES & YES & NO & NO & YES & YES \\
\hline Pre-existing LFP trends & NO & NO & NO & YES & NO & NO & NO & YES \\
\hline Individual fixed effects & NO & NO & NO & NO & YES & YES & YES & YES \\
\hline Observations & 6,537 & 6,537 & 6,480 & 6,453 & 6,537 & 6,537 & 6,480 & 6,453 \\
\hline R-squared & 0.009 & 0.061 & 0.102 & 0.100 & 0.024 & 0.064 & 0.068 & 0.068 \\
\hline Mean-Dependent Variable & 0.645 & 0.645 & 0.646 & 0.647 & 0.645 & 0.645 & 0.646 & 0.647 \\
\hline Num. of women in panel & & & & & 3,373 & 3,373 & 3,361 & 3,350 \\
\hline
\end{tabular}

Data from EPS survey, year 2004, 2006 and 2009. Women aged 25 to 55, who had school aged children when they were surveyed. Share of FDS schools is the fraction of schools with at all their grade levels under the FDS regime. Robust standard errors, clustered at the municipal level, in parentheses. ***, **, * reflect statistical significance at $1 \%, 5 \%$ and $10 \%$ levels, respectively. Not shown: region-year fixed effects, municipality fixed effects, interactions between a categorical variable for pre 2004 female labor force participation and year fixed effects, and individual fixed effects. 
Table 6

Effect of Full-Day Schooling for different grade levels on female labor outcomes

Outcome 1: Outcome 2: Outcome 3:

Participated in LF Participated in LF Fraction of year

any time during for $6+$ months in which

the year

during the year participated in LF

VARIABLES

(1)

(2)

FDS in 1st and 2nd grade (Share)

$0.356 * *$

$0.589 * * *$

(3)

$(0.170)$

(0.180)

$0.559 * * *$

FDS in 3rd through 6th grade (Share)

0.0553

0.250

(0.172)

(0.240)

(0.254)

0.228

FDS in 7st and 8th grade (Share)

$-0.0756$

$-0.308$

(0.246)

Years of schooling completed

(0.204)

(0.224)

$-0.279$

0.00599

0.00487

(0.217)

(0.00547)

(0.00584)

0.00660

Age

$-0.0155$

$-0.00178$

(0.00562)

(0.0222)

(0.0242)

$-0.00343$

Age-squared

$-0.000201$

$-0.000278$

(0.0231)

(0.000249)

(0.000273)

$-0.000244$

Municipal ave. school attainment

$-0.0343$

0.00553

(0.000261)

(0.0306)

(0.0308)

0.000985

0.0105

0.0927

(0.0300)

Municipal poverty rate

(0.201)

(0.211)

0.110

$-0.0576$

$-0.415$

(0.205)

Municipal unemployment rate

(0.419)

(0.444)

$-0.443$

Observations

6,453

6,453

(0.430)

R-squared

0.074

0.067

6,453

Mean-Dependent Variable

0.682

0.648

0.069

Num. of women in panel

3,350

3,350

0.647

Data from EPS survey, year 2004, 2006 and 2009. Women aged 25 to 55, who had school aged children when they were surveyed. FDS variables are the fraction of schools within Municipality that offer grade levels under the FDS regime. FDS in 1st and 2nd grade is the share of schools at the municipality level that offer 1st and 2nd grade under FDS. FDS in 3rd through 6th grade is the share of schools at the municipality level that offer 3rd, 4th, 5th, and 6th grade (simultaneously) under FDS. FDS in 7th and 8th grade is the share of schools at the municipality level that offer 7 th and 8th grade under FDS. Robust standard errors, clustered at the municipality level, in parentheses. ***, **, * reflect statistical significance at $1 \%, 5 \%$ and $10 \%$ levels, respectively. Not shown: region-year fixed, municipal and inidvidual fixed effects, pre-existing trends in labor force outcomes and constant. 
Table 7

Labor force participation outcomes by groups of mothers (sample averages)

\begin{tabular}{|c|c|c|c|c|c|c|c|c|c|c|}
\hline \multirow[b]{2}{*}{ Outcome: } & \multicolumn{2}{|c|}{$\begin{array}{c}\text { Mother's } \\
\text { year of birth }\end{array}$} & \multicolumn{2}{|c|}{$\begin{array}{l}\text { Civil Status } \\
\text { Married/ }\end{array}$} & \multicolumn{2}{|c|}{ Head of Household } & \multicolumn{2}{|c|}{$\begin{array}{l}\text { High education } \\
(12+\text { years })\end{array}$} & \multicolumn{2}{|c|}{$\begin{array}{c}\text { Had pre-school } \\
\text { aged child }\end{array}$} \\
\hline & $\begin{array}{c}\text { Before } \\
\text { '69 }\end{array}$ & $\begin{array}{c}1969 \text { or } \\
\text { after }\end{array}$ & $\begin{array}{c}\text { Married/ } \\
\text { Partner }\end{array}$ & Single & No & Yes & No & Yes & No & Yes \\
\hline In LF any time during the year & 65.7 & 70.9 & 60.8 & 85.9 & 63.2 & 80.7 & 58.2 & 74.5 & 71.2 & 60.3 \\
\hline In LF for $6+$ months during the year & 62.4 & 67.3 & 56.9 & 83.7 & 59.4 & 78.2 & 53.3 & 71.9 & 68.0 & 56.1 \\
\hline Fraction of year in which participated in LF & 62.3 & 67.2 & 56.7 & 83.6 & 59.3 & 78.0 & 53.2 & 71.8 & 67.9 & 55.9 \\
\hline
\end{tabular}

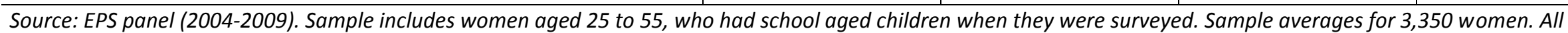
reported averages of labor force participation outcomes are different across groups at a statistical significance level of $1 \%$. 
Effect of Full-Day Schooling at the Municipal level on female labor outcomes for different groups of mothers.

\begin{tabular}{|c|c|c|c|c|c|c|c|c|c|c|c|c|c|c|c|}
\hline \multirow[b]{3}{*}{ VARIABLES } & \multicolumn{3}{|c|}{$\begin{array}{c}\text { Mother's year } \\
\text { of birth } \geq 1969 \\
\text { Outcome: }\end{array}$} & \multicolumn{3}{|c|}{$\begin{array}{c}\text { Mother is single } \\
\text { Outcome: }\end{array}$} & \multicolumn{3}{|c|}{$\begin{array}{c}\text { Mother is head } \\
\text { of household } \\
\text { Outcome: }\end{array}$} & \multicolumn{3}{|c|}{$\begin{array}{c}\text { Mother completed } \\
\text { at least high school } \\
\text { Outcome: }\end{array}$} & \multicolumn{3}{|c|}{$\begin{array}{c}\text { Mother has preschool } \\
\text { aged children } \\
\text { Outcome: }\end{array}$} \\
\hline & 1 & 2 & 3 & 1 & 2 & 3 & 1 & 2 & 3 & 1 & 2 & 3 & 1 & 2 & 3 \\
\hline & $(1)$ & $(2)$ & (3) & (4) & $(5)$ & $(6)$ & (7) & (8) & (9) & $(10)$ & $(11)$ & $(12)$ & $(13)$ & $(14)$ & $(15)$ \\
\hline $\begin{array}{l}\text { Share FDS schools in } \\
\text { Municipality }\end{array}$ & $\begin{array}{c}0.370 * * \\
(0.177)\end{array}$ & $\begin{array}{c}0.552 * * \\
(0.215)\end{array}$ & $\begin{array}{c}0.531 * * * \\
(0.204)\end{array}$ & $\begin{array}{l}0.339 * \\
(0.191)\end{array}$ & $\begin{array}{c}0.460 * * \\
(0.206)\end{array}$ & $\begin{array}{c}0.432 * * \\
(0.199)\end{array}$ & $\begin{array}{l}0.360 * \\
(0.189)\end{array}$ & $\begin{array}{c}0.485^{* *} \\
(0.225)\end{array}$ & $\begin{array}{c}0.479 * * \\
(0.212)\end{array}$ & $\begin{array}{l}0.387^{*} \\
(0.202)\end{array}$ & $\begin{array}{c}0.515^{* *} \\
(0.245)\end{array}$ & $\begin{array}{c}0.487^{* *} \\
(0.237)\end{array}$ & $\begin{array}{l}0.345^{*} \\
(0.184)\end{array}$ & $\begin{array}{c}0.459 * * \\
(0.205)\end{array}$ & $\begin{array}{r}0.433^{* *} \\
(0.195)\end{array}$ \\
\hline $\begin{array}{l}\text { Share FDS * Mother's } \\
\text { YOB } \geq 1969\end{array}$ & $\begin{array}{l}-0.144 \\
(0.263)\end{array}$ & $\begin{array}{l}-0.179 \\
(0.249)\end{array}$ & $\begin{array}{l}-0.166 \\
(0.251)\end{array}$ & & & & & & & & & & & & \\
\hline $\begin{array}{l}\text { Share FDS * Mother is } \\
\text { single }\end{array}$ & & & & $\begin{array}{l}-0.268 \\
(0.379)\end{array}$ & $\begin{array}{l}-0.265 \\
(0.378)\end{array}$ & $\begin{array}{l}-0.237 \\
(0.362)\end{array}$ & & & & & & & & & \\
\hline $\begin{array}{l}\text { Share FDS * Mother is } \\
\text { Head Household }\end{array}$ & & & & & & & $\begin{array}{l}-0.416 \\
(0.331)\end{array}$ & $\begin{array}{l}-0.0231 \\
(0.434)\end{array}$ & $\begin{array}{l}-0.0698 \\
(0.394)\end{array}$ & & & & & & \\
\hline $\begin{array}{l}\text { Share FDS * Mother } \\
\text { completed at least high } \\
\text { school }\end{array}$ & & & & & & & & & & $\begin{array}{l}-0.146 \\
(0.296)\end{array}$ & $\begin{array}{l}-0.0672 \\
(0.327)\end{array}$ & $\begin{array}{c}-0.0634 \\
(0.316)\end{array}$ & & & \\
\hline $\begin{array}{l}\text { Share FDS * Mother has } \\
\text { preschooler }\end{array}$ & & & & & & & & & & & & & $\begin{array}{l}-0.374 \\
(0.387)\end{array}$ & $\begin{array}{l}-0.254 \\
(0.411)\end{array}$ & $\begin{array}{c}-0.210 \\
(0.399)\end{array}$ \\
\hline Observations & 6,453 & 6,453 & 6,453 & 6,453 & 6,453 & 6,453 & 6,453 & 6,453 & 6,453 & 6,453 & 6,453 & 6,453 & 6,453 & 6,453 & 6,453 \\
\hline R-squared & 0.101 & 0.092 & 0.096 & 0.108 & 0.113 & 0.115 & 0.117 & 0.108 & 0.111 & 0.097 & 0.097 & 0.096 & 0.126 & 0.114 & 0.118 \\
\hline P-value FDS variables & 0.098 & 0.031 & 0.027 & 0.203 & 0.080 & 0.092 & 0.163 & 0.036 & 0.034 & 0.113 & 0.035 & 0.042 & 0.166 & 0.085 & 0.087 \\
\hline Mean-Dep. Variable & 0.682 & 0.648 & 0.647 & 0.682 & 0.648 & 0.647 & 0.682 & 0.648 & 0.647 & 0.682 & 0.648 & 0.647 & 0.682 & 0.648 & 0.647 \\
\hline Num. women in panel & 3,350 & 3,350 & 3,350 & 3,350 & 3,350 & 3,350 & 3,350 & 3,350 & 3,350 & 3,350 & 3,350 & 3,350 & 3,350 & 3,350 & 3,350 \\
\hline
\end{tabular}

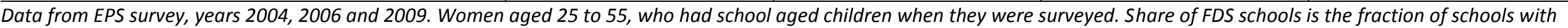

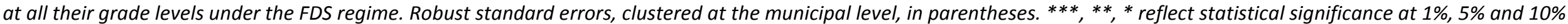

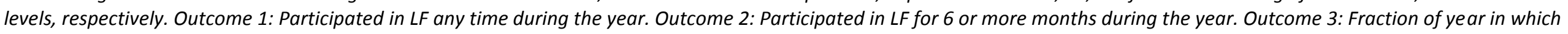

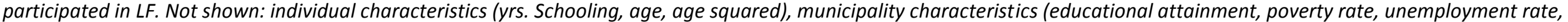

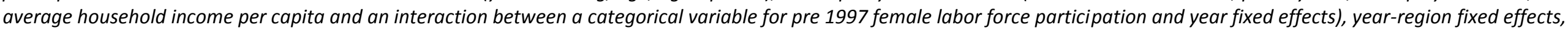

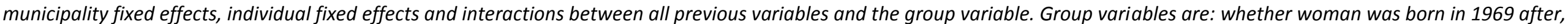

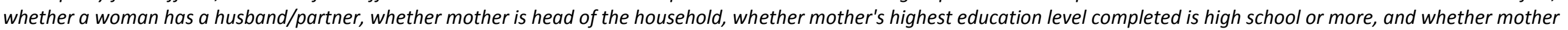
also has a child of preschool age. 
Table 9

Robustness estimates of the Effect of Full-Day Schooling at the Municipal level on female labor outcomes.

\begin{tabular}{|c|c|c|c|c|c|c|c|c|c|c|c|c|}
\hline & \multicolumn{3}{|c|}{$\begin{array}{c}\text { Mother's without children } \\
\text { in primary school age } \\
\text { Outcome: }\end{array}$} & \multicolumn{3}{|c|}{$\begin{array}{c}\text { Men } \\
\text { Outcome: }\end{array}$} & \multicolumn{3}{|c|}{$\begin{array}{c}\text { Excluding } 2009 \text { survey } \\
\text { Outcome: }\end{array}$} & \multicolumn{3}{|c|}{$\begin{array}{c}\text { No Large } \\
\text { Metropolitan Areas } \\
\text { Outcome: }\end{array}$} \\
\hline VARIABLES & $\begin{array}{c}1 \\
(1) \\
\end{array}$ & $\begin{array}{c}2 \\
(2) \\
\end{array}$ & $\begin{array}{c}3 \\
(3) \\
\end{array}$ & $\begin{array}{c}1 \\
(4) \\
\end{array}$ & $\begin{array}{c}2 \\
(5) \\
\end{array}$ & $\begin{array}{c}3 \\
(6) \\
\end{array}$ & $\begin{array}{c}1 \\
(7) \\
\end{array}$ & $\begin{array}{c}2 \\
(8) \\
\end{array}$ & $\begin{array}{c}3 \\
(9) \\
\end{array}$ & $\begin{array}{c}1 \\
(10) \\
\end{array}$ & $\begin{array}{c}2 \\
(11) \\
\end{array}$ & $\begin{array}{c}3 \\
(12) \\
\end{array}$ \\
\hline Share of FDS schools in Municipality & $\begin{array}{l}0.00148 \\
(0.0815)\end{array}$ & $\begin{array}{c}0.0944 \\
(0.0837)\end{array}$ & $\begin{array}{c}0.0626 \\
(0.0832)\end{array}$ & $\begin{array}{l}-0.0464 \\
(0.0718)\end{array}$ & $\begin{array}{l}-0.0884 \\
(0.0759)\end{array}$ & $\begin{array}{l}-0.0895 \\
(0.0753)\end{array}$ & $\begin{array}{c}0.269 \\
(0.277)\end{array}$ & $\begin{array}{c}0.476 \\
(0.294)\end{array}$ & $\begin{array}{l}0.483 * \\
(0.271)\end{array}$ & $\begin{array}{l}0.395^{* *} \\
(0.151)\end{array}$ & $\begin{array}{c}0.517^{* * *} \\
(0.192)\end{array}$ & $\begin{array}{c}0.523 * * * \\
(0.185)\end{array}$ \\
\hline Observations & 12,860 & 12,860 & 12,860 & 5,568 & 5,568 & 5,568 & 4,568 & 4,568 & 4,568 & 3,369 & 3,369 & 3,369 \\
\hline R-squared & 0.063 & 0.059 & 0.061 & 0.079 & 0.069 & 0.073 & 0.095 & 0.087 & 0.085 & 0.090 & 0.076 & 0.082 \\
\hline Mean-Dependent Variable & 0.647 & 0.647 & 0.647 & 0.647 & 0.647 & 0.647 & 0.647 & 0.647 & 0.647 & 0.647 & 0.647 & 0.647 \\
\hline Num. of individuals in panel & 6,164 & 6,164 & 6,164 & 2,959 & 2,959 & 2,959 & 2,973 & 2,973 & 2,973 & 1,716 & 1,716 & 1,716 \\
\hline
\end{tabular}

Data from EPS survey, years 2004, 2006 and 2009. Share of FDS schools is the fraction of schools with at all their grade levels under the FDS regime. Robust standard errors, clustered at the municipal level, in parentheses. ${ }^{* * *},{ }^{* *},{ }^{*}$ reflect statistical significance at $1 \%, 5 \%$ and $10 \%$ levels, respectively. Outcome 1 : Participated in LF any time during the year. Outcome 2: Participated in LF for 6 or more months during the year. Outcome 3: Fraction of year in which participated in LF. Not shown: individual characteristics (yrs. Schooling, age, age squared), municipality characteristics (educational attainment, poverty rate, and unemployment rate), year-region fixed effects, municipality fixed effects, individual fixed effects and interactions between all previous variables and the group variable. Samples are: mother's without children in primary school age; men aged 25 to 55; baseline sample excluding 2009; and baseline sample excluding the three large metropolitan areas: Santiago, Concepcion and Valparaiso. Santiago includes all municipalities (comunas) in the XIII region, Concepcion includes Concepcion, Talcahuano, Sand Pedro de la Paz, Hualpen and Penco municipalities, and Valparaiso includes Valparaiso, Viña del Mar, Con-Con, Quilpue and Villa Alemana municipalities. 


\section{Table 10}

Determinants of Migration at the individual level (2006-2009)

\begin{tabular}{|c|c|c|}
\hline \multirow[b]{2}{*}{ VARIABLES } & \multicolumn{2}{|c|}{ Outcome: Mother migrated } \\
\hline & $(1)$ & $(2)$ \\
\hline \multirow[t]{2}{*}{ Years of schooling completed } & $0.00343^{* *}$ & -0.00720 \\
\hline & $(0.00137)$ & $(0.00525)$ \\
\hline \multirow[t]{2}{*}{ Mother has a partner } & 0.0117 & 0.0335 \\
\hline & $(0.0124)$ & $(0.0212)$ \\
\hline \multirow[t]{2}{*}{ Head of Household } & $0.0424 * * *$ & 0.0141 \\
\hline & $(0.0124)$ & $(0.0166)$ \\
\hline \multirow[t]{2}{*}{ Age } & -0.00746 & -0.0115 \\
\hline & $(0.00764)$ & $(0.0223)$ \\
\hline \multirow[t]{2}{*}{ Age-squared } & $6.46 e-05$ & $-5.85 e-05$ \\
\hline & $(9.63 e-05)$ & $(0.000251)$ \\
\hline \multirow[t]{2}{*}{ Share of FDS schools in Municipality (Destiny) } & -0.160 & -0.0666 \\
\hline & $(0.165)$ & $(0.117)$ \\
\hline \multirow[t]{2}{*}{ Share of FDS schools in Municipality (Origin) } & 0.383 & -0.119 \\
\hline & $(0.353)$ & $(0.372)$ \\
\hline \multirow[t]{2}{*}{ Municipal ave. school attainment (Destiny) } & -0.0197 & 0.0478 \\
\hline & $(0.0392)$ & $(0.0338)$ \\
\hline \multirow[t]{2}{*}{ Municipal ave. school attainment (Origin) } & 0.0212 & $0.137 * * *$ \\
\hline & $(0.0569)$ & $(0.0518)$ \\
\hline \multirow[t]{2}{*}{ Municipal poverty rate (Destiny) } & -0.302 & 0.0656 \\
\hline & $(0.349)$ & $(0.251)$ \\
\hline \multirow[t]{2}{*}{ Municipal poverty rate (Origin) } & -0.0525 & 0.350 \\
\hline & $(0.872)$ & $(0.576)$ \\
\hline \multirow[t]{2}{*}{ Municipal unemployment rate (Destiny) } & 0.753 & 0.146 \\
\hline & $(0.546)$ & $(0.443)$ \\
\hline \multirow[t]{2}{*}{ Municipal unemployment rate (Origin) } & 1.475 & 0.589 \\
\hline & $(1.411)$ & $(0.742)$ \\
\hline Individual fixed effects & NO & YES \\
\hline Observations & 4,038 & 4,038 \\
\hline R-squared & 0.176 & 0.391 \\
\hline Mean-Dependent Variable & 0.105 & 0.105 \\
\hline Num. of women in panel & & 2,648 \\
\hline
\end{tabular}

Data from EPS survey, years 2006 and 2009. Women aged 25 to 55, who had school aged children when they were surveyed. Share of FDS schools is the fraction of schools with at all their grade levels under the FDS regime. Robust standard errors, clustered at the municipal level, in parentheses. ${ }^{* *}, * *, *$ reflect statistical significance at 1\%,5\% and 10\% levels, respectively. Migration status: categorical variable equals to 1 if the mother lives in a different municipality than in the previous survey (2006 versus 2004 and 2009 versus 2006). Not shown: yearregion fixed effects, municipality fixed effects, and individual fixed effects in column 2. 